Estuarine, Coastal and Shelf Science

April 2017, Volume 189, Pages 189-202

http://dx.doi.org/10.1016/j.ecss.2017.03.010

http://archimer.ifremer.fr/doc/00374/48551/

(c) 2017 Elsevier Ltd. All rights reserved.

\title{
Decline of cold-water fish species in the Bay of Somme (English Channel, France) in response to ocean warming
}

\author{
Auber Arnaud ${ }^{1,}$, , Gohin Francis ${ }^{2}$, Goascoz Nicolas ${ }^{3}$, Schlaich Ivan ${ }^{3}$ \\ ${ }^{1}$ IFREMER, Laboratoire Ressources Halieutiques, 150 quai Gambetta, BP699, 62321 Boulogne-sur- \\ Mer, France \\ 2 IFREMER, Département Dynamiques de l'Environnement côtier, Centre Ifremer Brest, BP 70, 29280 \\ Plouzané, France \\ ${ }^{3}$ IFREMER, Laboratoire Ressources Halieutiques, Avenue du Général de Gaulle, BP32, 14520 Port-en- \\ bessin, France \\ * Corresponding author : Arnaud Auber, email address : $\underline{\text { Arnaud.Auber@ifremer.fr }}$
}

\begin{abstract}
:
A growing number of studies have documented increasing dominance of warm-water fish species ("tropicalisation") in response to ocean warming. Such reorganization of communities is starting to occur in a multitude of local ecosystems, implying that tropicalisation of marine communities could become a global phenomenon. Using 32 years of trawl surveys in the Bay of Somme (English Channel, France), we aimed to investigate the existence of a tropicalisation in the fish community at the local scale of the estuary during the mid-1990s, a period where an exceptional temperature rise occurred in Northeast Atlantic. A long-term response occurred (with a major transition over 6 years) that was characterized by a marked diminution in the abundance of cold-water species in parallel to a temperature rise generated by the ocean-scale phenomenon, the Atlantic Multidecadal Oscillation, which switched from a cool to a warm phase during the late 1990s. Despite finding no significant increase in the dominance of warmwater species, the long-term diminution of cold-water species suggests that the restructuring of the fish community was mainly influenced by global-scale environmental conditions rather than local ones and that indirect effects may also occurred through biological interactions.
\end{abstract}




\section{Introduction}

One of the main challenges in ecology is to understand how biodiversity responds to environmental changes, and the consequences this can generate for ecosystem functioning, especially when aiming to anticipate long-term biological responses to future environmental changes (Bengtsson, 1998) and predict impacts on ecosystem services (Duffy et al., 2007). In marine environments, community structure is highly variable and depends on both natural and human-induced environmental variation (Collie et al., 2004), which may act concomitantly (Chavez et al., 2003), rendering the quantification of their relative contributions difficult (Beaugrand, 2004).

Among human-induced environmental variation, climate change alters environmental conditions including global temperature, sea-ice extent, nitrogen levels in the biosphere, atmospheric and oceanic carbon dioxide concentrations which tend to affect water acidity (Doney et al., 2009), oxygen availability (Koenigstein et al., 2016), rainfall patterns, wind, biogeochemical cycles (Zepp et al., 2003) including salinity (Durack et al., 2012), frequency of extreme weather events, sea level, ocean circulation (IPCC, 2007), thermal stratification of water-columns (Hordoir and Meier, 2012), and the size of the oxygen minimum zone (Stramma et al., 2010). Climate change has a wide variety of effects on the physiology, distribution and phenology of marine organisms (IPCC, 2014) (Perry et al., 2005; Cheung et al., 2009; Cheung et al., 2013) including phytoplankton (e.g., Wetz et al., 2011; Rossoll et al., 2012), zooplankton (e.g., Hays et al., 2005, Richardson, 2008), fishes (e.g., Cheung et al., 2012b; Pinsky and Fogarty, 2012; Perry et al., 2005; Hawkins et al., 2013), birds (e.g., Şekercioğlu et al., 2012; Niven et al., 2009), and marine mammals (e.g., McMahon and Burton, 2005; Learmonth et al., 
60 2006), which ultimately affects humans (Patz et al., 2005; McMichael et al., 2006). These

61 impacts are fundamentally linked to the close relationship between ocean conditions and

62 the ecophysiology of marine organisms, notably water-breathing ectotherms (Somero

63 2010; Sunday et al., 2011).

64 Climate change has mainly been characterized by an ongoing rise in the global 65 temperature of the world's oceans since the mid-20 ${ }^{\text {th }}$ century (IPCC, 2007), which can be

66 more or less pronounced in different regions (Belkin, 2009; Alexander et al., 2014).

67 Water temperature is recognized as an abiotic "master factor" controlling physiological 68 processes of aquatic organisms (Beitinger and Fitzpatrick, 1979; Singh et al., 2013), and 69 therefore controls the behaviour, growth, metabolism, abundance and species 70 composition of fishes (e.g., Thiel et al., 1995; Stenseth et al., 2002), notably in estuarine 71 ecosystems (Thiel et al., 1995; Harrison and Whitfield, 2006). Marine fishes mainly 72 respond to temperature increases through changes in distribution (e.g., Perry et al., 2005), 73 generally to higher latitudes (Parmesan, 2006; Mueter and Litzow, 2008; Jung et al., 74 2014; Punzón et al., 2016) and deeper waters (Dulvy et al., 2008; Punzón et al., 2016). 75 Latitudinal shifts can also result in changes in community composition through 76 increasing dominance by tropical or subtropical fish species preferring warm-waters.

77 Such a reorganization of fish communities, or so-called "tropicalisation", appears to be

78 occurring in a multitude of local ecosystems, suggesting that this reorganization of

79 marine communities could become a global phenomenon (Verges et al., 2014). Previous

80 works have indicated that tropicalisation of fish communities has occurred in response to

81 global warming in several areas/scales, including Western Australia (Cheung et al., 82 2012a), the Aegean Sea (Keskin and Pauly, 2014), Italian seas (Fortibuoni et al., 2015) 
83 and in fisheries of Large Marine Ecosystems (Cheung et al., 2013). In addition to

84 potential cascading effects within biological communities, modifications in species assemblages may lead to substantial impacts on socio-economic components (Chapin et al., 2000, Cheung et al., 2012a).

In the North Atlantic, several natural climate oscillations also occur and act concomitantly with human-induced climate change. Over the last three decades in northeast Atlantic marine systems, abundant evidence of natural, climate-driven changes in biotic assemblages has been mounting. Among natural climate cycles, the Atlantic Multidecadal Oscillation (AMO) reflects natural oscillations of sea surface temperature (SST) from cool to warm phases with a periodicity varying between 60 and 80 years (Edwards et al., 2013; Auber et al., 2015). The AMO is progressively considered as a "proxy for complex processes in the coupled atmosphere-ocean system of the North Atlantic" (Alheit et al. 2014a); this system involves the North Atlantic Oscillation (NAO), the Atlantic Meridional Overturning Circulation (AMOC), the Mediterranean Overflow Water (MOW) and the subpolar gyre (Hátún et al., 2009; Alheit et al., 2014b). Alheit et al., (2014b) indicated that these complex climatic processes began building in the North Atlantic in the 1960s and culminated in the 1990s, which had pervasive ecosystem and ecological repercussions. In the Western English Channel, the AMO is synchronous with the Russell Cycle (Russell et al., 1971; Edwards et al., 2013), which has characterized profound changes in species' abundances and distributions since the mid-19 ${ }^{\text {th }}$ century, including fishes (Alheit et al., 2014b; Mieszkowska et al., 2014). Another well-known climate cycle, the NAO, corresponds to decadal variations in atmospheric and oceanic circulation in the North Atlantic (Dickson and Turrell, 2000). 
106 This climate phenomenon has been widely announced as a major forcing factor acting on

107 marine communities (Fromentin and Planque, 1996; Beaugrand et al., 2002) because it

108 affects precipitation patterns, which can influence river run-off and therefore nutrient

109 inputs, salinity, and turbidity (e.g. Enfield et al., 2001; Trigo et al., 2004; Harley et al.,

110 2006). The NAO and AMO are partly linked through atmospheric-oceanic circulation

111 coupling, since SST depends and acts upon atmospheric circulation (Drinkwater et al.,

112 2014; Harris et al., 2014).

113 Several studies have shown SST warming from 0.2 to $0.6^{\circ} \mathrm{C}$ in the North Atlantic

114 since the late 1980s (Dulvy et al., 2008; Wang and Dong, 2010), with exceptional

115 warming after the mid-1990s (Wang and Dong, 2010), notably in the English Channel

116 (Saulquin and Gohin, 2010). The combined effects of anthropogenic climate change and

117 the positive phase of the AMO after the 1990s may have caused higher warming in the

118 North Atlantic than would be expected from climate change alone (Andronova and

119 Schlesinger, 2000; Knudsen et al., 2011). Such a strong temperature rise during the late-

120 1990s raises the question of whether a tropicalisation also occurred at local scales. A

121 recent work (Auber et al., 2015) documented a persistent structural change in the

122 exploited fish community of the Eastern English Channel in the mid-1990s, characterized

123 by a strong decrease of cold-water fish species and a moderate increase of warm-water

124 species, which was synchronous with a change from a cold to a warm phase of the AMO.

125 According to these authors, a question remains of whether this community change was or

126 was not visible at even more local scales than the Eastern English Channel, notably in

127 fish nursery ecosystems. 
Estuaries are essential ecosystems for the life cycles of many fish species (Lipcius

129 et al., 2008; Nicolas et al., 2010) since they act temporarily as nursery and feeding areas

130 for marine juveniles, offering a highly nutrient-rich environment and shallow turbid

131 refuges suitable for development (Potter et al., 1990; Nicolas et al., 2010). Additionally,

132 fish species encompass a wide diversity of biological cycles and ecological

133 compartments, making them relevant indicators of estuarine conditions at multiple spatial

134 and temporal scales (Whitfield and Elliott, 2002). In Northern France, the estuarine

135 ecosystem of the Bay of Somme provides a nursery area for many species of the English

136 Channel (Rybarczyk et al., 2003) that shifted spatially during the late-1990s, likely in

137 response to the AMO switch. Because several tropicalisation events have occurred in

138 multiple local ecosystems, because an exceptional temperature rise occurred in the mid-

139 1990s in Northeast Atlantic, and because the Bay of Somme constitutes a nursery for fish

140 species living in the Eastern English Channel (where many species shifted during the

141 late-1990s), we suspect that a tropicalisation also occurred in the Bay of Somme during

142 this period.

143 Based on the ecosystem of the Bay of Somme (English Channel, France), the

144 aims of this study are (i) to investigate the temporal dynamics of the taxonomic structure

145 of the fish community, (ii) to better understand the underlying mechanisms of community

146 dynamics in this estuary by assessing the respective effects of global climate-related

147 conditions and local conditions in the Bay, and (ii) to investigate, through a functional

148 approach, the potential tropicalisation of this community during the last 32 years in

149 response to temperature rise. 


\section{2. Materials and Methods}

$153 \quad 2.1$ Study site and Fish community sampling

154 The Bay of Somme $\left(50^{\circ} 14^{\prime} \mathrm{N}, 1^{\circ} 33^{\prime} \mathrm{E}\right.$; Figure 1$)$ is the second largest coastal ecosystem

155 in Northwestern France, after the Seine Estuary (Rybarczyk et al., 2003). With an

156 intertidal surface of more than $50 \mathrm{~km}^{2}$, the Bay is a macrotidal system of the Eastern

157 Channel (Rybarczyk et al., 2003) and is fed by the Maye River in north and the Somme

158 River in south (Figure 1). Marine influences dominate, making this complex ecosystem

159 mostly a marine bay with an estuary system reduced to the channel of the Somme

160 (Rybarczyk et al., 2003).

161 The fish community (including cephalopods) of the Bay of Somme was sampled

162 through the ecological and fisheries monitoring of the CNPE of Penly (Centrale

163 Nucléaire de Production d'Electricité) in late summer of each year since 1987.

164 Gastropods and crustaceans were not considered since the gear used was adapted to 165 harvest fishes, not benthic invertebrates. The study period was chosen in order to 166 maximize the availability of juveniles. Thus, since 1987, monitoring has been conducted

167 annually according to an experimental protocol that has remained unchanged through

168 time. The sampling scheme was defined according to three depth strata (see Figure 1).

169 The stratified sampling scheme aimed to achieve 44 hauls, 28 hauls using a beam trawl

170 with a 3-m horizontal opening (CP3) and a 20-mm stretched mesh size in strata B and C,

171 and 16 hauls using a beam trawl with a 2-m horizontal opening (CP2) and a 20-mm

172 stretched mesh size in stratum A. The vertical opening was $0.5 \mathrm{~m}$ for both beam trawls. 
173 All CP2 hauls lasted 7 min while CP3 hauls lasted 15 min. These trawling lines were

174 carried out during daylight hours at an average speed of 2.5 knots.

Fig. 1 here

177 Within each haul, fish species were identified, counted and weighed. A total of 62

178 taxonomic groups were recorded over the study period. All abundance values were 179 standardized to numbers of individuals per $\mathrm{km}^{2}$.

\subsection{Global conditions}

182 The North Atlantic Oscillation (NAO) is an intradecadal, basin-scale alternation of

183 atmospheric mass over the North Atlantic between the high atmospheric pressure

184 centered on the Azores and low atmospheric pressure around Iceland (Dickson and

185 Turrell, 2000). The index used here is based on the difference in normalized sea level

186 atmospheric pressure between Lisbon, Portugal and Stykkisholmur/Reykjavik, Iceland

187 since 1864 (Dickson and Turrell, 2000). During the positive phase of the NAO, Northern

188 Europe is exposed to warm, wet conditions with both more frequent and stronger winter

189 storms crossing the Atlantic Ocean in a northerly track (Reid et al., 2001; Ottersen et al.,

190 2001; Walker and Graf, 2005). The opposite trends occur during the negative phase:

191 fewer and weaker winter storms, a west-east pathway, and cold, dry conditions in

192 Northern Europe. Concerning biotic compartments, the NAO has already led to shifts in

193 phytoplankton abundance and species composition, followed by changes in the dominant

194 zooplanktonic species, Calanus spp., in the North Sea (Fromentin and Planque, 1996).

195 For fishes, the NAO is now considered as a driver acting on assemblage composition, 
196 abundance, and juvenile growth (Attrill and Power, 2002). Additionally, from one fish

197 species to another, the influence of NAO on recruitment may vary, notably in European

198 Shelf seas (Dippner, 1997; Attrill and Power, 2002). The annual NAO index for the

199 period 1988-2011 was obtained from the National Oceanographic and Atmospheric

200 Administration (NOAA, US).

201 The Atlantic Multidecadal Oscillation (AMO) refers to a 60-80 year cycle of the

202 North Atlantic SST (Edwards et al., 2013). Its determinants are not fully understood nor

203 are they predictable. The AMO index is computed as a monthly area-weighted average of

204 SST anomalies over the North Atlantic (from 0 to $70^{\circ} \mathrm{N}$ ). The obtained time series is then

205 detrended in order to remove the effect of global warming. This index has recently been

206 reported to influence plankton and fish abundance in some North Atlantic ecosystems

207 (Edwards et al., 2013; Alheit et al., 2014b). AMO values were provided by NOAA, US.

208 Northern Hemisphere air temperature anomalies $\left(\mathrm{NHT}_{\text {anomalies }}\right)$ were also used in

209 this work. This index is indicative of temperature conditions at a global scale; it reflects

210 both human and natural variations, and previous work (Beaugrand et al., 2002) indicated

211 that NHT anomalies could play a synergistic role with NAO on SST in the Northeast

212 Atlantic and thus on marine biota. NHT anomalies have already been correlated with the

213 abundance/biomass of several biological compartments: phytoplankton, zooplankton,

214 fishes (Beaugrand et al., 2002; Beaugrand and Reid, 2003) and also with community

215 indices like species richness of calanoid copepods in the northwestern North Atlantic

216 (Beaugrand et al., 2002). The values of $\mathrm{NHT}_{\text {anomalies }}$ were calculated from the average

217 temperature over the period 1950-2014 and produced by the Hadley Centre Research and

218 Climate Prediction (MetOffice, 2014). 


\subsection{Local conditions}

221 Sea surface temperatures were extracted from a database provided by the Hadley center,

222 Met Office (http://www.metoffice.gov.uk/hadobs/hadisst/). The data were interpolated to 223 provide a 1-month resolution SST dataset composed of in situ and satellite data 224 (advanced very high resolution radiometer). SST values were interpolated from this 225 database from 1980 to 2012 from nodes of a $1^{\circ}$ latitude-longitude spatial grid (Rayner et $226 a l ., 2003$ ) located between $50^{\circ} 17^{\prime} \mathrm{N}$ and $50^{\circ} 6^{\prime} \mathrm{N}$, and $1^{\circ} 24 \mathrm{~W}$ and $1^{\circ} 40 \mathrm{E}(2$ nodes located 227 in the Bay of Somme). Annual mean SST values were computed over this area $228\left(\mathrm{SST}_{\text {HadISST }}\right)$.

229 Additional SST values were obtained from the Ifremer SST data derived from 230 AVHRR/Pathfinder products interpolated by kriging (Saulquin and Gohin, 2010) for the 231 period 1986-2009, the OSTIA data provided by the Met Office using the Operational 232 SST and Sea Ice Analysis (OSTIA) system described in Donlon et al., (2011) for 2010, 233 and the ODYSSEA data, also derived from multi-sensor data incorporating microwave 234 instruments, provided by MyOcean (Autret and Piollé, 2011) for 2011-2012. A 235 comparison with a homogeneous time series covering the entire period, stemming from 236 global low-resolution GHRSST, showed that the inhomogeneity of the high-resolution 237 time series used here did not generate bias (L'Hévéder et al., 2016). The three sets of 238 satellite-derived SST data were projected onto the same regular grid --- $0.075^{\circ}$ in 239 longitude and $0.05^{\circ}$ in latitude --- allowing a relatively high spatial resolution of about 5 $240 \mathrm{~km} \times 5 \mathrm{~km}$. SST was assessed from this satellite dataset at each sampling site and date 
241 from the year when this trawl was performed. The mean of all temperature values within

242 each year was then calculated and used in this work $\left(\mathrm{SST}_{\text {sat }}\right)$.

243 Other SST values were collected through in situ measurements carried out during

244 the ecological monitoring of the CNPE of Penly. The mean between April, July and

245 September sessions from 1989 to 2012 were used in this work (SST $\left.{ }_{\text {hydro }}\right)$. Finally, SST

246 and bottom temperatures measured were also included in this work (mean between May

247 and June sessions: SST $_{\text {ichtyo }}$ and BottomTEMP).

248 Salinity can also influence fish community structure through physiological

249 responses at the individual scale (e.g., Peterson and Meador, 1994; Rowe and Dunson,

250 1995). Bottom and surface salinity were obtained through the ecological monitoring of

251 the CNPE of Penly (the mean between May and June sessions was used in this work). For

252 this work, the mean between bottom and surface values was used as an index of salinity

253 in the overall water column.

254 Ecosystem productivity, which is usually assessed through the concentration of 255 chlorophyll a (Cravo et al., 2010; Horta e Costa et al., 2014) can also influence the 256 structure of fish communities through trophic cascades. Concentration of chlorophyll $a$ 257 was recorded during the ecological monitoring of the CNPE of Penly (the mean between 258 April, July and September sessions was used for this study). Additional Chlorophyll $a$ 259 data were extracted from satellite data (Gohin, 2011). Chlorophyll $a$ concentrations were 260 assessed from the satellite dataset at each sampling site and date when each trawling line 261 was performed. For each year, the mean between all Chl. a values (i.e., between all 262 trawling lines during the survey period) was used. 
The concentration of suspended matter has previously been documented as a non-

264 negligible factor that can affect aquatic organisms through "disruptions in migrations and

265 spawning, movement patterns, sublethal effects like disease susceptibility, growth, and

266 development, reduced hatching success, and direct mortality" (Kjelland et al., 2015). The

267 concentration of suspended matter was recorded during the ecological monitoring of the

268 CNPE of Penly from 1980 to 2012. The mean between April, July and September

269 sessions was used for this study. Non-algal suspended matter was also obtained from

270 satellite data from 1998 to 2015 (Gohin et al., 2005; Gohin, 2011). These data were

271 assessed from the satellite dataset at each sampling site and date when each trawling line

272 was performed. For each year, the mean between all satellite-derived suspended matter

273 concentrations was used (i.e., between all trawling lines during the survey period).

274 Among meteorological parameters, rainfall has often been identified as one of the

275 main forces acting on the structure of fish communities (e.g., Castillo-Rivera et al., 2002;

276 Meynecke et al., 2006). River flow, which is directly linked to rainfall, was also included

277 in this study because nutrient content, and thus ecosystem productivity, may vary with

278 river flow. Summer river flow (mean from July to September) from 1980 to 2015 was

279 available from the Data Centre for French Coastal Operational Oceanography (Fichaut et

280 al., 2011). Rainfall data (mean between July, August and September at Noyelles-sur-Mer;

281 Figure 1) from 1980 to 2015 were extracted from the Météo France website

282 (https://donneespubliques.meteofrance.fr/). Wind speed can also act as a forcing factor, as

283 several studies have already shown that wind may influence recruitment dynamics,

284 predator-prey relationships, and assemblage structure (e.g., Menge and Menge, 2013;

285 Horta e Costa et al., 2014). Therefore, wind speed (mean between July, August and 
286 September at Dieppe; see Figure 1) and air temperature (annual mean: AirTemp at

287 Dieppe), from 1980 to 2015, were also extracted from the Météo France website 288 (https://donneespubliques.meteofrance.fr/).

\subsection{Analysis of community structure changes}

291 Only taxa with abundances above $0.1 \%$ of total abundance across the study period were 292 included in this study (Kortsch et al., 2012), which resulted in a collection of 49 taxa. 293 Spatially aggregated abundance indices at the scale of the whole Bay of Somme were 294 used in the analyses described below. Aggregated indices were computed for each 295 species and each year as the mean of the numbers of individuals per $\mathrm{km}^{2}$ between all 296 trawling lines. The resulting data was a matrix of spatially aggregated abundance indices 297 per species (columns) and per year (lines) that represents the times series of community's 298 taxonomic structure.

A correlation-based Principal Component Analysis was performed on the species 300 abundance matrix in order to characterize temporal changes in the fish community (see 301 PCA biplot in supplementary material S1.A.). The two first components of the PCA $302\left(\mathrm{PC} 1_{\text {taxo }}\right.$ and $\left.\mathrm{PC} 2_{\text {taxo }}\right)$ were used as indices of community structure.

303 The existence and timing of potential shifts in community structure was assessed 304 by chronological clustering using a multivariate regression tree (MRT) with the species 305 abundance matrix as the explained matrix and time as the explanatory variable (Borcard 306 et al., 2011). The shift in community structure was first characterized by testing for 307 changes in the abundance of each species, between the period before and that after the 308 shift. A Monte-Carlo permutation test was then performed on the spatially aggregated 
309 abundance indices using the "max statistic" method described below in order to account

310 for the increase in the family-wise type 1 error rate due to multiple testing (Groppe et al.,

311 2011). Lines of the species abundance matrix corresponding to years were randomly

312 permuted between the period before and that after the shift. This randomized any

313 potential association between the abundance index of each species and the period, while

314 preserving any correlative structure between species abundance indices themselves. A

315 one-way ANOVA with period as the explanatory factor was then performed on the

316 abundance index of each species in the permuted matrix, and the maximum $F$ value

317 across species was recorded. This procedure was repeated 5000 times and the resulting

318 distribution of permuted maximum $\mathrm{F}$ values was used as the empirical null distribution

319 against which observed $\mathrm{F}$ values, computed through one-way ANOVAs on the actual

320 time series of species average abundance indices, were tested. A change in species

321 abundance was declared significant when less than $5 \%$ of the permuted maximum $\mathrm{F}$

322 values were larger than the observed $\mathrm{F}$ value.

323 In order to assess potential changes in the community in terms of balance between 324 warmer-water and colder-water species, the MTC index (Cheung et al., 2013) was 325 computed from the average inferred temperature preference of species weighted by their 326 density:

$$
M T C=\frac{\sum_{i}^{n} T i . C i}{\sum_{i}^{n} C i}
$$

328 Here $\mathrm{Ci}$ corresponds to the density of species $i$ (nb.ind. $\left./ \mathrm{km}^{2}\right), T i$ corresponds to the 329 thermal preference of species $I$, and $n$ is the total number of species. Thermal preference 330 of each species was obtained from Cheung et al. (2013). First, a one-way ANOVA with 
331 period as the explanatory factor was performed on the MTC index. Second, in order to

332 identify which members of the community (cold-water or warm-water species) mostly

333 contributed to temporal changes of MTC, several groups of species were built based upon

334 their thermal preferences (e.g., $\left.\left[11-12^{\circ} \mathrm{C}\right]\right)$. As for the abundance of each species, the max

335 statistic method was used to test for differences in the abundance of each thermal

336 preference group between compared time periods.

\subsection{Effects of global and local conditions on community structure}

339 The dynamics of global conditions were assessed using the first principal component

340 ( $\left.\mathrm{PC} 1_{\text {global }}\right)$ coordinates of a correlation-based PCA applied to the matrix of variables

341 relative to global conditions (see supplementary material S1.B; variables: NAO, AMO,

$\left.342 \mathrm{NHT}_{\text {anomalies }}\right)$. The same procedure was used for local conditions $\left(\mathrm{PC}_{\text {local }}\right.$; variables: sea

343 surface temperature, air temperature, suspended matters, river flow, rainfall, wind speed,

344 Chl. $a$ and salinity; see supplementary material S1.C). The Pearson correlations between

$345 \mathrm{PC} 1_{\text {global }}$ and $\mathrm{PC}_{\text {taxo }}$ and between $\mathrm{PC} 1_{\text {local }}$ and $\mathrm{PC} 1_{\text {taxo }}$ were then investigated through a 346 cross-correlation analysis at several time-lags (0 to 6 years).

347 Temporal changes in the fish community were also assessed by analyzing a

348 "thermal matrix" containing the abundance of 14 groups defined by thermal preferences $\left.\left.\left.\left.349\left(\left[7-8^{\circ} \mathrm{C}\right],\right] 8-9^{\circ} \mathrm{C}\right], \ldots,\right] 20-21^{\circ} \mathrm{C}\right]\right)$. Like with the taxonomic approach, the shift(s) in

350 community structure was/were characterized by testing for changes in the abundance of 351 each thermal group, between the period before and that after each shift by using the max 352 statistic method (Groppe et al., 2011). A correlation-based Principal Component Analysis 353 was performed on the thermal matrix and the coordinates of the first principal component 
354 ( $\left.\mathrm{PC} 1_{\text {therm }}\right)$ were used in order to describe the dynamics of the "thermal structure" of the

355 community. Additionally, cross-correlation analyzes were performed between the MTC

356 index and all indices relative to temperature $\left(\mathrm{SST}_{\text {sat }}, \mathrm{SST}_{\text {HadISST }}, \mathrm{SST}_{\text {hydro }}, \mathrm{SST}_{\text {ichtyo }}\right.$,

357 BottomTEMP, AirTemp, AMO, $\mathrm{NHT}_{\text {anomalies }}$ and NAO) with time-lags ranging from 0 to

3583 years. In order to investigate which index (i.e., $\mathrm{PC} 1_{\text {taxo }}$ or $\mathrm{PC}_{\text {therm }}$ ) mostly responded to

359 AMO, p-values and determination coefficients of a cross-correlation analysis between the

360 AMO index and $\mathrm{PC} 1_{\text {therm }}$ were compared to those provided by the cross-correlation

361 between the $\mathrm{AMO}$ index and $\mathrm{PC}_{\text {taxo }}$ (with several time-lags ranging from 0 to 3 years).

362 Finally, the same procedure was performed with the "local SST" variable (i.e., the mean

363 between all SST variables: $\mathrm{SST}_{\text {sat }}, \mathrm{SST}_{\text {HadISST }}, \mathrm{SST}_{\text {hydro }}, \mathrm{SST}_{\text {ichtyo }}$, BottomTEMP).

364 Statistical analyzes were performed using the R software version 3.1.3 (R Core

365 Team, 2015). Potential temporal autocorrelations of explained variables (i.e., $\mathrm{PC} 1_{\text {taxo }}$ and

$366 \mathrm{PC}_{\text {therm }}$, and the MTC index) were checked before all statistical analyses, and effects

367 were declared statistically significant with an alpha value of 0.05 .

369 3. Results

$370 \quad 3.1$ Temporal changes of the fish community

371 The multivariate regression tree of community data against time detected the existence of

372 a significant change in community structure in 1998 (permutation test: $p<0.001$ ). This

373 change represents $34 \%$ of community structure variation over the overall study period. In

374 view of the first and second principal components extracted from the PCA (see

375 Supplementary material S1.A.) and applied on the fish community matrix (PC1 and PC2

376 explained 20 and $10 \%$ of total variation, respectively), the change in the taxonomic 
377 structure of the fish community especially occurred from 1998 to 2003 (Figure 2). As

378 indicated by the first principal component, the taxonomic structure was relatively stable 379 before 1998 and quickly changed until 2003, before stabilizing again (Figure 2). 380 Similarly, the second principal component also indicated 1998 as the breaking year 381 (Figure 2).

Fig. 2 here

384 The change in community structure was characterized by a diminution in the abundance 385 of the majority of species during the mid-1990s (Figure 3). In the overall fish community, 386 five taxa significantly decreased in abundance from the period "before 1998" to the 387 period "after 1998": Gobiidae family (permutation test: $p<0.001$ ), Callionymus lyra 388 (Dragonet; $p=0.004)$, Limanda limanda (Dab; $p=0.008)$, Pleuronectes platessa (Plaice; $389 p=0.004$ ), and Sprattus sprattus (sprat; $p=0.008$ ), whereas only one genus, Arnoglossus 390 (Scaldfish), significantly increased in abundance $(p=0.023)$ (Figure 3).

Fig. 3 here

394 3.2. Effects of environmental conditions on the taxonomic structure of the fish community

395 Significant relationships were found between the global conditions index $\left(\mathrm{PC}_{\text {global }}\right.$ : $82 \%$ 396 of total variation; Supplementary material S1.B.) and the structure of the fish community 397 (PC1 $1_{\text {taxo }}: 20 \%$ of total variation) with $0,1,2,4,5$ and 6-year lags (Figure 4A), and a 
398 significant correlation was observed with the local conditions index ( $\mathrm{PC}_{\text {local }}$ : $33 \%$ of

399 total variation; Supplementary material S1.C.) with a 2-year lag (Figure 4B).

Fig. 4 here

401

402 3.3. Effects on the thermal structure of the fish community

403 In parallel with a significant temperature rise in the Bay of Somme $(p<0.05)$ and the 404 switch from a cold to a warm phase of the AMO, the MTC index increased at an average 405 rate of $0.2{ }^{\circ} \mathrm{C}$ per decade from 1987 to 2012 , especially from the mid-1990s to early 4062000 s (Figure 5), and significantly increased from $11.49 \pm 0.36$ to $11.91 \pm 0.45{ }^{\circ} \mathrm{C}$ 407 between the periods "before 1998" and "after 1998" (ANOVA: F(1,28) = 7.075, $p<$ 408 0.05). Significant positive correlations were detected between MTC and the majority of 409 temperature-related variables: $\mathrm{SST}_{\text {sat }}$ (time lag $=0$ year), $\mathrm{SST}_{\text {HadISST }}$ (time lag $=0$ year), $410 \operatorname{SST}_{\text {ichtyo }}$ (time lag $=0$ year), AirTemp (time lag $=0$ and 1 year), NHT $_{\text {anomalies }}$ (time lag $=$ 4110 and 1 year) and AMO (time lag $=0$ and 3 years) (see Table 2 for detailed results).

Fig. 5 here

414 According to Figures $6 \mathrm{~A}$ and $6 \mathrm{~B}$, the increase of the MTC index was especially due to a 415 decrease in the abundance of species preferring cold-waters. Significant diminutions in 416 abundance were observed for three thermal groups: $\left[9-10^{\circ} \mathrm{C}\right],\left[10-11^{\circ} \mathrm{C}\right]$, and $\left[11-12^{\circ} \mathrm{C}\right]$ 417 (Figure 6A). We also observed that several species with significant diminutions 418 (Gobiidae family, Callionymus lyra, Limanda limanda; Figure 3) belonged to the [11$\left.41912^{\circ} \mathrm{C}\right]$ thermal group, which largely explains the significant decrease of this group. The 
420 two last species showing a significant decrease (Pleuronectes platessa and Sprattus 421 sprattus), belonged to the $\left[9-10^{\circ} \mathrm{C}\right]$ thermal group, and thus contributed to the significant 422 decrease of this group. Figure 6B indicates that flounders (Platichthys flesus), which did 423 not significantly change in abundance, also contributed to the decrease of the $\left[9-10^{\circ} \mathrm{C}\right]$ 424 thermal group. The $\left[10-11^{\circ} \mathrm{C}\right]$ thermal group, represented by mackerel (Scomber 425 scombrus), sculpins (Cottidae family), whiting (Merlangius merlangus), European eel 426 (Anguilla anguilla), European pollock (Pollachius pollachius) and lemon sole 427 (Microstomus kitt), showed a significant decrease, although no individual species 428 significantly decreased over time. Despite observing some abundance increases for 429 "warm-water species" these increases were not significant (e.g., Sardina pilchardus, 430 Mullus surmuletus), except for Arnoglossus, which was characterized by intermediate 431 thermal preference (Figure 6B). A significant change occurred in the thermal structure of 432 the community (characterized by a decrease in the dominance of cold-water species) 433 between the two periods (permutation test: $p<0.001$ ). A significant positive correlation 434 was also observed between the amplitude of abundance variation and thermal preference 435 (Pearson's $\mathrm{r}=0.342, p=0.022$; Figure 6B), and a significant difference was noted 436 between the thermal preferences of species that decreased in abundance and the thermal 437 preferences of species that increased in abundance (ANOVA: $\mathrm{F}(1,43)=6.376, p=0.015$; 438 Figure 6C). 
442 The AMO index was significantly correlated to the taxonomic structure of the community

443 with 1 and 2 year time-lags and significantly correlated to the thermal structure of the 444 community for all tested time-lags (Figure 7A, 7B and Table 1). In parallel, local SST 445 was not significantly correlated with $\mathrm{PC} 1_{\text {taxo }}$ or $\mathrm{PC} 1_{\text {therm }}$ (for any time-lag) (Figure 7C, $4467 \mathrm{D}$ and Table 1). We can note here that all local temperature-related variables in the Bay 447 of Somme were positively and significantly correlated to the global AMO index (SST sat $_{\text {: }}$ $448 \quad p<0.05$ with time-lag $=4$ years; SST $_{\text {HadISST }}: p<0.001$ for time-lag $=0$ and 1 year, and $p$ $449<0.01$ for time-lag $=2$ years; AirTemp: $p<0.001$ for time-lag $=1$ and $p<0.01$ for time$450 \quad$ lag $=0$ and 2 years $).$

The results ( $\mathrm{p}$-values and $\mathrm{R}^{2}$ coefficients) extracted from cross-correlation 452 analyzes between $\mathrm{PC}_{\text {therm }}$ and $\mathrm{AMO}$ compared to those relative to the correlation 453 between $\mathrm{PC}_{\text {taxo }}$ and $\mathrm{AMO}$ revealed that, whatever the considered time-lag, the thermal 454 structure of the community was better correlated to the AMO than to taxonomic structure 455 (Table 1). This result was not observed with local SST, except with time lag $=3$ years. 456

Table 1 here

460 4. Discussion

461 Our analyses revealed a noteworthy change in the structure of the Bay of Somme fish 462 community at the end of 1990s (from 1998 to 2003) that was related to an increase of 463 SST at the global scale. This change in the fish community was mainly characterized by a 464 decrease in the abundance of species preferring cold-waters. Several other fish species 
465 (bream, squids from the loliginidae family, sardine, red mullet), characterized by higher 466 thermal preference, increased (non-significantly) in abundance over time. These 467 dynamics, which led to the observed increase of the MTC index, are in line with 468 numerous works (e.g., Perry et al., 2005; Cheung et al., 2012a; Fortibuoni et al., 2015, 469 Tsikliras et al., 2014, 2015) documenting a tropicalisation of fish communities in 470 response to temperature rise. Such a tropicalisation is characterized by an increase in the 471 dominance of warm-water species in temperate areas in response to ocean warming 472 (Cheung et al., 2013). Our results differ from what we expected and from the majority of 473 documented tropicalisations in the sense that the response of the community to warming 474 was mainly characterized by a diminution in the abundance of cold-water species rather 475 than an increase of warm-water species. We also noticed that, at the local scale of the Bay 476 of Somme, the MTC index increased at a similar rate $\left(0.2^{\circ} \mathrm{C} / \mathrm{dec}\right.$ ade $)$ to the rate of 477 increase of non-tropical MTC observed at the global scale $\left(0.23^{\circ} \mathrm{C} /\right.$ decade, according to 478 Cheung et al., 2013) during the last four decades.

Whatever the considered approach (taxonomic or functional), the fish community 480 has changed in relation to temperature conditions measured at the local scale of the bay, 481 which appear themselves highly dependent on global conditions. A reason that could 482 explain why global conditions (especially conducted by the AMO and NHT) mainly 483 determined the community structure at the local scale is that certain fish species do not 484 spend their entire life cycle in the Bay of Somme, which indicates that they might also be 485 exposed to other conditions (e.g., at the basin-wide scale of the English Channel, North 486 Sea). Species rely on different coastal habitats to fulfill their life cycles (Seitz et al., 487 2014), therefore, habitat quality and connectivity are considered essential characteristics 
488 of coastal ecosystems (Lipcius et al., 2008). For example, adult common sole (Solea

489 solea) spawn in the continental shelf whereas juveniles grow in coastal nurseries where 490 environmental conditions differ, notably in water temperature (MacPherson and Duarte, 491 1991).

In this study, most of the local temperature variables were significantly correlated with the AMO index, which therefore suggests that the Bay of Somme is substantially 494 dependent on global phenomena like climate oscillations, although several local processes occur. We therefore inferred that the long-term increase in local SST, which is reflected by the AMO index, was the main forcing factor affecting the structure of the

497 fish community. The idea that temperature was a major contributing forcing factor was 498 reinforced by the fact that the MTC index was correlated with the majority of temperature 499 measures and several time lags. Much more significant correlations were indeed observed 500 between community indices and global conditions (i.e., many more time lags above zero) 501 than between community indices and local conditions (see for example Table 1 and 502 Figure 4). This potentially means that the fish community may have presented a longterm response to global conditions during the last three decade.

The long-term characteristic of the response (over 6 years here) of the fish community notably suggests the existence of indirect effects through biological interactions (that may necessitate delays in response time) like trophic cascades following

507 direct effects on other biological compartments (e.g., phyto-zooplankton and benthic 508 macroinvertebrates), or direct impacts on the growth of larvae and/or juveniles, or on the 509 physiology of adults like fecundity that potentially generate inter-cohort effects. Long510 term responses at community scale are increasingly detected in marine ecosystems like 
511 for example in the North Sea, where Daan et al. (2005) observed a minimum of 6 year-

512 lagged response of fish communities to indirect effects of fishing pressure. Our

513 understanding of long-term changes in exploited fish communities necessitates to

514 consider numerous aspects like species interactions (Ferretti et al., 2013) that are now

515 recognized as one of the main driving mechanism leading to community changes over

516 time and space (Ferretti et al., 2010). In a next step, investigating how the trophic

517 structure of the entire biocoenose (or at least the fish community) have changed over time

518 in the Bay of Somme will be therefore extremely helpful to better understand the reason

519 leading to the observed long-term response. The long-term characteristic of the response

520 can be also explained by several other mechanisms like physiological effects of sea

521 warming on fish larvae and/or juvenile and/or adults, or also progressive shifts in

522 latitudinal distributions. We present in Figure 8 potential processes that may explain the 523 community changes.

$524 \quad$ First, potential changes in fish community structure may have occurred following 525 the physical movement of fishes, possibly in response to climate-induced latitudinal shifts 526 in food resources (e.g., zoo-planktonic communities, Beaugrand et al., 2002; Perry et al., 527 2005) or the direct influence of temperature increase (Figure 8). Fish movements may 528 have been encouraged by northeastward water masses flowing into the Channel in the 529 mid-1990s from the Bay of Biscay, which characterized the beginning of a new warm 530 phase (positive AMO index values) (Mieszkowska et al., 2014). Several cold-water fish 531 species (e.g., Scomber scombrus, Trisopterus luscus, Trisopterus minutus) decreased in 532 abundance in the Bay of Somme, showing opposite trends to what has been observed 533 since the mid-1990s in the North Sea (Beare et al., 2004; Astthorsson et al., 2012). As 
534 proposed by these authors, our results also support the hypothesis of a northward

535 migration of fishes from the Channel to the North Sea in response to ocean warming. In

536 parallel, we documented a decrease in the abundance of sprats and herring, two cold-

537 water species, similar to previous observations in the Eastern, North, and Central Atlantic

538 Seas, which also varied in synchrony with warm and cool AMO phases (Alheit et al.,

$5392012,2014 b)$. We also observed an increase in the abundance of some warm-water

540 species (e.g., red mullet: Mullus surmuletus; although non-significant), similar to

541 previous studies (Cheung et al., 2012b), which observed an increase in catches of red

542 mullet (Mullus barbatus) around the UK in response to ocean warming. In the same

543 manner, we observed similar trends to those presented by several authors concerning

544 sardine, another warm-water species, which increased in abundance in response to AMO

545 variations in the Western English Channel, North Sea, and Baltic Sea (Petitgas et al.,

546 2012; Alheit et al., 2012) through northward migrations, particularly in the mid-1990s

547 (Alheit et al., 2014b). Several works have documented northward movements of

548 Lusitanian fish species into the English Channel, Celtic and North Seas over the last few

549 decades (Perry et al., 2005; ter Hofstede et al., 2010; Simpson et al., 2011; Petitgas et al., 550 2012).

Fig.8 here

553 Second, the observed changes in the fish community may be the result of 554 modifications in hydrodynamic connectivity between habitats that are vital for successive 555 life-stages, especially for eggs and larvae that depend highly on ocean circulation (Figure 556 7; Kendall et al., 2016). We can suppose that larval dispersion patterns were modified 
557 following the exceptional inflow of oceanic water in the mid-1990s (Toresen and Østvedt

558 2000; Mieszkowska et al., 2014). According to Kendall et al. (2016), climate change is

559 "predicted to alter ocean currents that transport eggs and young larvae through changes in

560 atmospheric circulation and ocean stratification," which may therefore impact the

561 structure of the fish community.

562 Third, fish recruitment may have been affected by temperature rise through:

563 (i) physiological effects on larval and/or juvenile growth and mortality rates

564 (Pepin, 1991; Green and Fisher, 2004; Genner et al., 2010) (Figure 8). For example,

565 Arula et al., (2015) showed that exceeding the physiological thermal preferences of fish

566 larvae can cause decreased growth rates and increased mortality. In the specific case of

567 this study in the Bay of Somme, despite no significant increase in the abundance of warm

568 water species was observed, the temperature increase may have improved juvenile

569 growth rates, resulting in higher recruitment and abundance of certain of these species

570 (Nye et al., 2014). In contrast, the temperature increase may have reduced the growth

571 rates of cold-water species, leading to substantial diminutions in abundance.

572 (ii) physiological effects on adults themselves (Figure 8; Rijnsdorp et al., 2009),

573 which could cause changes in community dynamics. A study on tropical fish species

574 (Pankhurst and Porter, 2003) showed that relatively small changes in temperature lead to

575 changes in fishes' endocrine systems, which by consequence influenced reproductive

576 activity. However, for some species, areas that were previously unsuitable may have

577 become more favourable (Cheung et al., 2013). Complementary investigations on the

578 temperature tolerance range of species rather than their thermal preferences would be 
579 useful, notably because rates of temperature variation may be decisive for fish 580 communities.

(iii) physiological effects on the prey of fish larvae and/or juveniles therefore causing a trophic cascade on fish larvae and/or juveniles themselves (e.g., Arula et al., 2015; Hátún et al., 2009) (Figure 8). Several observations have confirmed this climate-

584 induced change. For example, in the Western English Channel, the zooplanktonic 585 community quickly changed from large to small-sized copepods with warm-water 586 affinities in parallel to the AMO (Hátún et al., 2009; Eloire et al., 2010). This trophic 587 cascade hypothesis could therefore be tested by investigating spatio-temporal changes in 588 prey species within the Bay of Somme but also at a more global scale (at least the Eastern 589 English Channel scale). In opposite, the observed changes in fish community structure 590 may have led to a series of cascading effects through trophic relationships, potentially 591 impacting planktonic communities, seabirds or marine mammals. The study of 592 Hernandez-Farinas et al., (2014) indicated that several dinoflagellate genera and some 593 diatoms (e.g., Pseudo-nitzschia) increased from 2001 to 2007/2010 in the Bay of Somme 594 in relation to the AMO. Such an increase during the 2000s is probably linked to the 595 decrease of total fish abundances we describe in this study. In their work, Hernandez596 Farinas et al., (2014) also inferred that, in this estuary, global conditions (AMO and 597 NAO, especially AMO) may be stronger than local conditions in impacting the structure 598 of phytoplanktonic communities. Lefebvre et al., (2011) also showed that, in the Bay of 599 Somme, several exceptional changes occurred between the late 1990s and early 2000s, 600 such as an increase in chlorophyll $a$ concentration (from 1996 to 2005), an increase of the 601 standard molar ratio for dissolved inorganic nitrogen (from 1999 to 2003), and an 
602 increase in the density of phytoplanktonic cells (from 1999 to 2003), with exceptional

603 dominance of Prymnesiophyceae algae (especially Phaeocystis globosa). These results

604 therefore indicate that the changes we observed in the fish community also concerned

605 phytoplanktonic communities. According to Lefebvre et al., (2011), changes in the

606 phytoplanktonic compartment were mainly due to global climate processes through the

607 direct effects of AMO and NAO, but we can also suppose that indirect effects (e.g.,

608 trophic cascades) occurred. We can indeed assume that the Bay of Somme fish

609 community changes were due to the observed modification of the phytoplanktonic

610 community, and vice versa. Nonetheless, because the change in the fish community was

611 mainly characterized by a decrease of fish densities, and because thermal preference

612 appears to be a structuring trait, we believe that the fish community was directly

613 impacted by temperature increase and that phytoplanktonic communities (e.g., increase of

614 algae density) were both directly impacted by temperature increase and indirectly through

615 a top-down effect. We are therefore convinced that investigating the dynamics of the

616 phyto-zooplanktonic and macroinvertebrates communities of the Bay constitutes the best

617 next step for understanding the ecological mechanisms that occurred in this estuary.

618 Unfortunately, the effects of fishing were not assessed in this work because no

619 data were available. Despite its known catastrophic effects on fish assemblages, fishing

620 mortality has declined in the Northeast Atlantic since the beginning of 1990s (ter

621 Hofstede et al., 2010). However, the long history of exploitation in the EEC may have

622 facilitated the observed community change by rendering the entire fish community more

623 sensitive to climatic variations (Hsieh et al., 2006; Auber et al., 2015). Furthermore,

624 caution must be taken concerning the non-implication of fishing in the observed 
625 reorganization of the fish community, since several species spend part of their life cycle

626 in the open English Channel, an ecosystem that has been subjected to intense fishing

627 pressure for multiple decades, which can be also accompanied of time-lagged effects on

628 fish communities (e.g., Daan et al., 2005). Consequently, future investigations are needed

629 to assess the potential effects of fishing at the local scale of the bay, notably by focusing

630 initially on species that are known to move between the Bay of Somme and the English

631 Channel. constitutes an additional observation of 'tropicalisation' since it is now added to the

634 numerous previous works showing such type of community reorganization. It therefore

635 reinforces the hypothesis that a global scale phenomenon is occurring in fish

636 communities. This study also tends to show that the restructuring of the fish community

637 was mainly influenced by global-scale sea warming rather than local environmental

638 conditions. The response was characterized by a long-term change in the structure of the

639 community and thus reinforces the idea that the effect of warming is, the most often, not

640 detectable in the short term (Godbold and Solan, 2013). This highlights the necessity to

641 mostly consider the appropriate timescales for assessing ecological repercussions of

642 climate forcings (e.g., Hettinger et al., 2012; Godbold and Solan, 2013), especially in the

643 aim to better identify responsible drivers, to better understand mechanisms of action and

644 finally, to support decision making in the context of the policy adaptation to global

645 warming.

646 
648

649 Acknowledgments

650 We would especially like to acknowledge all persons involved in the NOURSOM survey

651 since 1980 on the professional boats. This study was supported by EDF (Electricité de

652 France; IGA project), Ifremer (Institut Français de Recherche pour exploitation de la mer;

653 ECLIPSE project), Région Hauts-de-France (ECLIPSE project), and the Foundation for

654 Research on Biodiversity (ECLIPSE project); contract no. astre 2014-10824). We

655 personally thank Matthew McLean for his contribution to the English writing of this

656 paper. We thank anonymous reviewers who improved the quality of this paper.

657

658 


\section{References}

Aiken, C.M., Navarrete, S.A., Pelegrí, J.L., 2011. Potential changes in larval dispersal and alongshore connectivity on the central Chilean coast due to an altered wind climate. J. Geophys. Res. 116,1-14.

Alexander, M.A., Halimeda, Kilbourne K., Nye, J.A., 2014. Climate variability during warm and cold phases of the Atlantic Multidecadal Oscillation (AMO) 18712008. J. Mar. Syst. 133,14-26.

Alheit, J., Drinkwater, K.F., Nye, J.A., 2014a. Introduction to Special Issue: Atlantic Multidecadal Oscillation-mechanism and impact on marine ecosystems. J. Mar. Syst. 133,1-3.

Alheit, J., Licandro, P., Coombs, S., Garcia, A., Giráldez, A., Santamaría, M.T.G., Slotte, A., Tsikliras, A.C., 2014b. Atlantic Multidecadal Oscillation (AMO) modulates dynamics of small pelagic fishes and ecosystem regime shifts in the eastern North and Central Atlantic. J. Mar. Syst. 131, 21-35.

Alheit, J., Pohlmann, T., Casini, M., Greve, W., Hinrichs, R., Mathis, M., O’Driscoll, K., Vorberg, R., Wagner, C., 2012. Climate variability drives anchovies and sardines into the North and Baltic Seas. Prog. Oceanogr. 96, 128-139.

Arula, T., Laur, K., Simm, M., Ojaveer, H., 2015. Dual impact of temperature on growth and mortality of marine fish larvae in a shallow estuarine habitat. Estuar. Coast. Shelf S. 167, 326-335.

Astthorsson, O.S., Valdimarsson, H., Gudmundsdottir, A., Oskarsson G.J., 2012. Climate-related variations in the occurrence and distribution of mackerel (Scomber scombrus) in Icelandic waters. ICES J. Mar. Sci. 69, 1289-1297. 
Attrill, M.J., Power, M., 2002. Climatic influence on a marine fish assemblage. Nature 417, $275-278$.

Auber, A., Travers-Trolet, M., Villanueva, M.C., Ernande, B., 2015. Regime Shift in an Exploited Fish Community Related to Natural Climate Oscillations. PloS one 10:e0129883.

Autret, E., Piolle, J.F., 2011. Product User Manual for ODYSSEA Level 3 and 4 Global and Regional Products. MYO-PUM-SST-TAC-ODYSSEA, Ifremer/CERSAT.

Beare, D. J., Burns, F., Greig, A., Jones, E.G., Peach, K., Kienzle, M., McKenzie, E., Reid, D.G., 2004. Long-term increases in prevalence of North Sea fishes having southern biogeographic affinities. Mar. Ecol. Prog. Ser. 284, 269-278.

Beaugrand, G., 2004. The North Sea regime shift : evidence, causes, mechanisms and consequences. Prog. Oceanogr. 60, 245-262.

Beaugrand, G., Reid, P.C., 2003. Long-term changes in phytoplankton, zooplankton and salmon related to climate. Glob. Change Biol. 9, 801-817.

Beaugrand, G., Reid, P.C., Ibañez, F., Lindley, J.A., Edwards, M., 2002. Reorganization of North Atlantic marine copepod biodiversity and climate. Science 296, 16921694.

Beitinger, T.L., Fitzpatrick, L.C., 1979. Physiological and ecological correlates of preferred temperature in fish. Am. Zool 19, 319-330.

Belkin, I.M., 2009. Rapid warming of Large Marine Ecosystems. Prog. Oceanogr. 81, 207-213. 
703 Bengtsson, J., 1998. Which species? What kind of diversity? Which ecosystem function? Some problems in studies of relations between biodiversity and ecosystem function. Appl. Soil Ecol. 10, 191-199.

706

707

708

709

710

Borcard, D., Gillet, F., Legendre, P., 2011. Numerical Ecology with R. Springer, New York. 258p.

Bozinovic, F., Pörtner, H.O., 2015. Physiological ecology meets climate change. Ecol. Evol. 5, 1025-1030.

Brander, K. M. 2007. Global fish production and climate change. P. Natl. Acad. Sci. 104, 19709-19714.

Castillo-Rivera, M., Zavala-Hurtado, J.A., Zárate-Hernández, R., 2002. Exploration of Spatial and Temporal Patterns of Fish Diversity and Composition in a Tropical Estuarine System of Mexico. Fish Biol. Fish. 12, 167-177.

Chapin, F.S.C., Zavaleta, E.S., Eviner, V.T., Naylor, R.L., Vitousek, P.M., Reynolds, H.L., Hooper, D.U., Lavorel, S., Sala, O.E., Hobbie, S.E., Mack, M.C., Díaz, S., 2000. Consequences of changing biodiversity. Nature. 405, 234-242.

Chavez, F.P., Ryan, J., Lluch-Cota, S.E., Niquen, M.C., 2003. From anchovies to sardines and back: multidecadal change in the Pacific Ocean. Science. 299, 21721.

Cheung, W.W.L., Lam, V.W.Y., Sarmiento, J. L., Kearney, K., Watson, R., Pauly, D., 2009. Projecting global marine biodiversity impacts under climate change scenarios. Fish Fish. 10, 235-251. 
724 Cheung, W.W.L., Meeuwig, J.J., Feng, M., Harvey, E., Lam, V.W.Y., Langlois, T., Slawinski, D., Sun, C., Pauly, D., 2012a. Climate-change induced tropicalisation of marine communities in Western Australia. Mar. Freshwater Res. 63, 415-427. Cheung, W.W.L., Pinnegar, J., Merino, G., Jones, M.C., Barange, M., 2012b. Review of climate change impacts on marine fisheries in the UK and Ireland: Climat change and Marine Fisheries in Ireland and the UK. Aquat. Conserv. 22, 368-388.

Cheung, W.W.L., Watson, R., Pauly, D., 2013. Signature of ocean warming in global fisheries catch. Nature 497, 365-368.

Collie, J.S., Richardson, K., Steele, J.H., 2004. Regime shifts: Can ecological theory illuminate the mechanisms? Prog. Oceanogr. 60, 281-302.

Cravo, A., Relvas, P., Cardeira, S., Rita, F., Madureira, M., Sánchez, R., 2010. An upwelling filament off southwest Iberia: effect on the chlorophyll $a$ and nutrient export. Cont. Shelf. Res. 30, 1601-1613.

Cushing, D.H., 1990. Plankton production and year-class strength in fish populations - an update of the match mismatch hypothesis. Adv. Mar. Biol. 26, 249-293.

Daan, N., Gislason, H., Pope, J.G., Rice, J.C., 2005. Changes in the North Sea fish community: evidence of indirect effects of fishing? ICES J. Mar. Sci. 62, 177188.

Dickson, R.R., Turrell, W.R., 2000. The NAO: The dominant atmospheric process affecting oceanic variability in home, middle and distant waters of European Atlantic salmon. In: Mills DH, Malden MA Fishing News Books editors. The Ocean Life of Atlantic Salmon: Environmental and Biological Factors Influencing survival. pp 92-115. 
747 Dippner, J.W., 1997. Recruitment success of different fish stocks in the North Sea in 748 relation to climate variability. Ger. J. Hydrobiol. 49, 277-293.

749 Doney, S.C., Fabry, V.J., Feely, R.A., Kleypas, J.A., 2009. Ocean Acidification: The Other $\mathrm{CO}_{2}$ Problem. Ann. Rev. Mar. Sci. 1, 169-192.

751 Donlon, C.J., Martin, M., Stark, J.D., Roberts-Jones, J., Fiedler, E., Wimmer, W., 2011.

752 The operational sea surface temperature and sea ice analysis (OSTIA) system. 753 Remote Sens. Environ. 116, 140-158.

754 Dray, S., Choler, P., Doledec, S., Peres-Neto, P.R., Thuiller, W., Pavoine, S., ter Braak, responses to environmental variation. Ecology 95, 14-21.

Drinkwater, K.F., Miles, M., Medhaug, I., Otterå, O.H., Kristiansen, T., Sundby, S., Gao Y., 2014. The Atlantic Multidecadal Oscillation: Its manifestations and impacts with special emphasis on the Atlantic region north of $60^{\circ}$ N. J. Mar. Syst. 133, 117-130.

Duffy, J.E., Bradley, J., France, K.E., McIntyre, P.B., 2007. The functional role of biodiversity in ecosystems : incorporating trophic complexity. Ecol. Lett. 10, 522-

764 Dulvy, N.K., Rogers, S.I., Jennings, S., Stelzenmller, V., Dye, S.R., Skjoldal, H.R., 2008. Climate change and deepening of the North Sea fish assemblage: a biotic indicator of warming seas. J. Appl. Ecol. 45, 1029-1039.

767 Durack, P.J., Wijffels, S.E., Matear, R.J., 2012. Ocean salinities reveal strong global water cycle intensification during 1950 to 2000 . Science $336,455-458$. 
769 Edwards, M., Beaugrand, G., Helaouët, P., Alheit, J., Coombs, S., 2013. Marine

770

771

772

773

774

775

776 Ecosystem Response to the Atlantic Multidecadal Oscillation. PLoS ONE 8:e57212.

Eloire, D., Somerfield, P.J., Conway, D.V.P., Halsband-Lenk, C., Harris, R., Bonnet, D., 2010. Temporal variability and community composition of zooplankton at station L4 in the Western Channel: 20 years of sampling. J. Plankton Res. 32, 657-679.

Enfield, D. B., Mestas-Nuñez, A.M., Trimble, P.J., 2001. The Atlantic multidecadal oscillation and its relation to rainfall and river flows in the continental US. Geophys. Res. Lett. 28, 2077-2080.

Ferretti, F., Osio, G.C., Jenkins C.J., Rosenberg A.A., Lotze, H.K., 2013. Long-term change in a meso-predator community in response to prolonged and heterogeneous human impact. Sci. rep. 3: 1057.

Ferretti, F., Worm, B., Britten, G.L., Heithaus, M.R., Lotze, H.K., 2010. Patterns and ecosystem consequences of shark declines in the ocean. Ecol. Lett. 13, 1055-1071.

Fichaut, M., Bonnat, A., Carval, T., Lecornu, F., Le Roux, J.F., Moussat, E., Nonnotte, L., Tarot, S., 2011. Data Centre for French Coastal Operational Oceanography. Med. Mar. Sci. special issue, 70-79.

Fortibuoni, T., Aldighieri, F., Giovanardi, O., Pranovi, F., Zucchetta, M., 2015. Climate impact on Italian fisheries (Mediterranean Sea). Reg. Env. Change 15, 931-937.

Fromentin, J.M., Planque B., 1996. Calanus and environment in the eastern North Atlantic. 2. Role of the North Atlantic Oscillation on Calanus finmarchicus and C. helgolandicus. Mar. Ecol. Prog. Ser. 134, 11-118. 
791 Garcia-Soto, C., Pingree R.D., 2012. Atlantic Multidecadal Oscillation (AMO) and sea 792 surface temperature in the Bay of Biscay and adjacent regions. J. Mar. Biol. Assoc. UK 92, 213-234.

794

795

796

797

798

Genner, M. J., Halliday, N.C., Simpson, S.D., Southward, A.J., Hawkins, S.J., Sims, D.W., 2010. Temperature-driven phenological changes within a marine larval fish assemblage. J. Plankton Res. 32, 699-708.

Godbold, J.A., Solan, M., 2013. Long-term effects of warming and ocean acidification are modified by seasonal variation in species responses and environmental conditions. Phil. Trans. Roy. Soc. B. 68: 20130186.

Gohin, F., 2011. Annual cycles of chlorophyll-a, non-algal suspended particulate matter, and turbidity observed from space and in-situ in coastal waters. Ocean Sci. 7, 705732.

Gohin, F., Loyer, S., Lunven, M., Labry, C., Froidefond, J.M., Delmas, D., Huret, M., Herbland, A., 2005. Satellite-derived parameters for biological modelling in coastal waters: Illustration over the eastern continental shelf of the Bay of Biscay. Remote Sens. Environ. 95, 29-46.

Green, B.S., Fisher, R., 2004. Temperature influences swimming speed, growth and larval duration in coral reef fish larvae. J. Exp. Mar. Biol. Ecol. 299, 115-132.

Groppe, D.M., Urbach T.P., Kutas M., 2011. Mass univariate analysis of event-related brain potentials/fields I: A critical tutorial review: Mass univariate analysis of ERPs/ERFs I: Review. Psychophysiol. 48, 1711-1725.

Harley, C.D.G., Randall Hughes, A., Hultgren, K.M., Miner, B.G., Sorte, C.J.B., Thornber, C.S., Rodriguez, L.F., Tomanek, L., Williams, S.L., 2006. The impacts 
of climate change in coastal marine systems: Climate change in coastal marine systems. Ecol. Lett. 9, 228-241.

Harris, V., Edwards, M., Olhede, S.C., 2014. Multidecadal Atlantic climate variability and its impact on marine pelagic communities. J. Mar. Syst. 133, 55-69.

Harrison, T.D., Whitfield, A.K., 2006. Temperature and salinity as primary determinants influencing the biogeography of fishes in South African estuaries. Estuar. Coast. Shelf S. 66, 335-345.

Hátún, H., Payne, M.R., Beaugrand, G., Reid, P.C., Sandø, A.B., Drange, H., Hansen, B., Jacobsen, J.A., Bloch, D., 2009. Large bio-geographical shifts in the north-eastern Atlantic Ocean: From the subpolar gyre, via plankton, to blue whiting and pilot whales. Prog. Oceanogr. 80, 149-162.

Hawkins, S.J., Firth, L.B., McHugh, M., Poloczanska, E.S., Herbert, R.J.H., Burrows, M.T., Kendall, M.A., Moore, P.J., Thompson, R.C., Jenkins, S.R., Sims, D.W., Genner, M.J., Mieszkowska, N., 2013. Data rescue and re-use: Recycling old information to address new policy concerns. Mar. Policy 42, 91-98.

Hays, G., Richardson, A., Robinson, C., 2005. Climate change and marine plankton. Trends Ecol. Evol. 20, 337-344.

Henderson, P.A., Bird, D.J., 2010. Fish and macro-crustacean communities and their dynamics in the Severn Estuary. Mar. Poll. Bull. 61, 100-114.

Hernandez-Farinas, T., Soudant, D., Barille, L., Belin, C., Lefebvre, A., Bacher, C., 2014. Temporal changes in the phytoplankton community along the French coast of the eastern English Channel and the southern Bight of the North Sea. ICES J. Mar. Sci. $71,821-833$. 
837 Hettinger A., Sanford, E., Hill, T.M., Russell, A.D., Sato, K.N.S., Hoey, J., Forsch, M., 838 Page, H.N., Gaylord, B., 2012. Persistent carry-over effects of planktonic exposure 839 to ocean acidification in the Olympia oyster. Ecology 93, 2758-2768.

840 Holmlund, C.M., Hammer, M., 1999. Ecosystem services generated by fish populations. Ecol. Econ. 29, 253-268.

Hordoir, R., Meier, H.E.M., 2012. Effect of climate change on the thermal stratification of the baltic sea: a sensitivity experiment. Clim. Dynam. 38, 1703-1713.

Horta e Costa, B., Assis, J., Franco, G., Erzini, K., Henriques, M., Gonçalves E.J., D.R.S., 2014. Tropicalization of fish assemblages in temperate biogeographic transition zones. Mar. Ecol. Prog. Ser. 504, 241-252.

Hsieh, C., Reiss, C.S., Hunter, J.R., Beddington, J.R., May, R.M., Sugihara, G., 2006. Fishing elevates variability in the abundance of exploited species. Nature 443, 859-862.

IPCC (2007). Summary for policymakers. In 'Climate Change 2007: the Physical Science Basis. Working Group I Contribution to the Fourth Assessment Report of the IPCC'. (Eds S. Solomon, Qin, D., Manning M.) pp. 1-18. (Cambridge University Press: Cambridge.).

IPCC (2014). Summary for policymakers. In: Climate Change 2014: Impacts, Adaptation, and Vulnerability. Part A: Global and Sectoral Aspects. Contribution of Working Group II to the Fifth Assessment Report of the Intergovernmental Panel on Climate Change [Field, C.B., Barros, V.R., Dokken, D.J., Mach, K.J., Mastrandrea, M.D., Bilir, T.E., Chatterjee, M., Ebi, K.L., Estrada, Y.O., Genova, R.C., Girma, B., 
Kissel, E.S., Levy, A.N., MacCracken, S., Mastrandrea, P.R., White, L.L. (eds.)]. Cambridge University Press, Cambridge, United Kingdom and New York, NY, USA, pp. 1-32.

Jung, S., Pang, I.C., Lee, J., Choi, I., Cha, H.K., 2014. Latitudinal shifts in the distribution of exploited fishes in Korean waters during the last 30 years: a consequence of climate change. Rev. Fish Biol. Fisher. 24, 443-462.

Kendall, M.S., Poti, M., Karnauskas, K.B., 2016. Climate change and larval transport in the ocean: fractional effects from physical and physiological factors. Glob. Change Biol. 22, 1532-1547.

Keskin, C., Pauly, D., 2014. Changes in the "Mean Temperature of the Catch": application of a new concept to the North-eastern Aegean Sea. Acta Adriat. 55, 213-218.

Kjelland, M.E., Woodley, C.M., Swannack, T.M., Smith, D.L., 2015. A review of the potential effects of suspended sediment on fishes: potential dredging-related physiological, behavioral, and transgenerational implications. Environ. Syst. Decis. $35,334-350$.

Kleisner, K.M., Coll, M., Lynam, C.P., Bundy, A., Shannon, L., Shin, Y.J., Boldt, J.L., Maria B.F., Diallo, I., Fox, C., Gascuel, D., Heymans, J.J., Juan Jordá, M.J., Jouffre, D., Large, S.I., Marshall, K.N., Ojaveer, H., Piroddi, C., Tam, J., Torres, M.A., Travers-Trolet, M., Tsagarakis, K., van der Meeren, G.I., Zador, S., 2015. Evaluating changes in marine communities that provide ecosystem services through comparative assessments of community indicators. Ecosyst. Serv. 16, 413-429. 
883 Knudsen, M.F., Seidenkrantz, M.S., Jacobsen, B.H., Kuijpers, A., 2011. Tracking the

884

885

886

887

888

889

890

891

892

893

894

895

896

897

898

899

900

901

902

903

904

905 Atlantic Multidecadal Oscillation through the last 8,000 years. Nature Comm. 2, $1-8$.

Koenigstein, S., Mark, F.C., Gößling-Reisemann, S., Reuter, H., Poertner, H.O., 2016. Modelling climate change impacts on marine fish populations: process-based integration of ocean warming, acidification and other environmental drivers. Fish Fish. http://dx.doi.org/10.1111/faf.12155.

Kortsch, S., Primicerio, R., Beuchel, F., Renaud, P.E., Rodrigues, J., Lønne, O.J., Gulliksen, B., 2012. Climate-driven regime shifts in Arctic marine benthos. P. Natl. Acad. Sci. USA 109, 14052-14057.

Kristiansen, T., Drinkwater, K.F., Lough, R.G., Sundby, S., 2011. Recruitment Variability in North Atlantic Cod and Match-Mismatch Dynamics. PLoS ONE 6:e17456.

Learmonth, J.A., MacLeod, C.D., Santos, M.B., Pierce, G.J., Crick, H.Q.P., Robinson, R.A., 2006. Potential effects of climate change on marine mammals. Oceanogr. Mar. Biol. 44, 431-464.

Lefebvre, A., Guiselin, N., Barbet, F., Artigas, F.L., 2011. Long-term hydrological and phytoplankton monitoring (1992-2007) of three potentially eutrophic systems in the eastern English Channel and the Southern Bight of the North Sea. ICES J. Mar. Sci. 68, 2029-2043.

L'Hévéder B., Speich S., Ragueneau O., Gohin F., Bryère P., 2016. Observed and projected sea surface temperature seasonal changes in the Western English Channel from satellite data and CMIP5 multi-model ensemble. Submitted in J. Clim. 
906 Lipcius, R.N., Eggleston, D.B., Schreiber, S.J., Seitz, R.D., Shen, J., Sisson, M.,

907

908

909

910

911

912

913

914

915

916

917

918

919

920

921

922

923

924

925

926

927

928

Stockhausen, W.T., Wang, H.V., 2008. Importance of Metapopulation

Connectivity to Restocking and Restoration of Marine Species. Rev. Fisher. Sci. $16,101-110$.

MacPherson E., Duarte C.M., 1991. Bathymetric trends in demersal fish size: is there a general relationship? Mar. Ecol. Prog. Ser. 71, 103-112.

McMahon, C.R., Burton, H.R., 2005. Climate change and seal survival: evidence for environmentally mediated changes in elephant seal, Mirounga leonina, pup survival. P. Roy. Soc. Biol. Sci. 272, 923-928.

McMichael, A.J., Woodruff, R.E., Hales, S., 2006. Climate change and human health: present and future risks. The Lancet 367, 859-869.

Menge, B.A., Menge D.N.L., 2013. Dynamics of coastal metaecosystems: the intermittent upwelling hypothesis and a test in rocky intertidal regions. Ecol. Monogr. 83, 283-310.

Meteorological Office, Hadley Centre for Climate Prediction and Research (London, UK). Available: http://cdiac.ornl.gov/trends/temp/jonescru/data.html

Météo France. Wind speed, rainfall and air temperature values. Available: https://donneespubliques.meteofrance.fr/. Accessed 2016 March 17.

Meynecke, J.O., Lee, S.Y., Duke, N.C., Warnken, J., 2006. Effect of Rainfall as a Component of Climate Change on Estuarine Fish Production in Queensland, Australia. Estuar. Coast. Shelf S. 69, 491-504.

Mieszkowska, N., Burrows, M.T., Pannacciulli, F.G., Hawkins, S.J., 2014. Multidecadal signals within co-occurring intertidal barnacles Semibalanus balanoides and 
Chthamalus spp. linked to the Atlantic Multidecadal Oscillation. J. Mar. Syst. $133,70-76$.

931

932

Mueter, F.J., Litzow, M.A., 2008. Sea ice retreat alters the biogeography of the Bering Sea continental shelf. Ecol. Appl. 18, 309-320.

Munday, P.L., Leis, J.M., Lough, J.M., Paris, C.B., Kingsford, M.J., Berumen, M.L., Lambrechts, J., 2009. Climate change and coral reef connectivity. Coral Reefs 28, 379-395.

Nicolas, D., Lobry, J., Le Pape, O., Boët, P., 2010. Functional diversity in European estuaries: Relating the composition of fish assemblages to the abiotic environment. Estuar. Coast. Shelf S. 88, 329-338.

Niven, D.K., Butcher, G.S., Bancroft, G.T., 2009. Birds and Climate Change: Ecological Disruption in Motion. National Audubon Society, New York, NY.

Nye, J.A., Baker, M.R., Bell, R., Kenny, A., Kilbourne, K.H., Friedland, K.D., Martino, E., Stachura, M.M., Van Houtan, K.S., Wood, R., 2014. Ecosystem effects of the Atlantic Multidecadal Oscillation. J. Mar. Syst. 133, 103-116.

Ottersen, G., Planque, B., Belgrano, A., Post, E., Reid, P.C., Stenseth N.C., 2001. Ecological effects of the North tlantic Oscillation. Oecologia 128, 1-14.

Ottersen, G., Alheit, J., Drinkwater, K., Friedland, K., Hagen, E., 2004. Marine Ecosystems Climate Variation. 91p.

Pankhurst, N.W., Porter, M.J.R., 2003. Cold and dark or warm and light: variations on the theme of environmental control of reproduction. Fish Physiol. Bioch. 28, 385389. 
951 Parmesan, C., 2006. Ecological and Evolutionary Responses to Recent Climate Change. Ann. Rev. Ecol. Evol. Syst. 37, 637-669.

Patz, J.A., Campbell-Lendrum, D., Holloway, T., Foley, J.A., 2005. Impact of regional climate change on human health. Nature 438, 310-317.

Pepin, P., 1991. Effect of Temperature and Size on Development, Mortality, and Survival Rates of the Pelagic Early Life History Stages of Marine Fish. Can. J. Fisher. Aquat. Sci. 48, 503-518.

Perry, A.L., Low, P.J., Ellis, J.R., Reynolds, J.D., 2005. Climate Change and Distribution Shifts in Marine Fishes. Science 308, 1912-1915.

Peterson, M.S., Meador, M.R., 1994. Effects of salinity on freshwater fishes in coastal plain drainages in the southeastern U.S. Rev. Fish. Sci. 2, 95-121.

Petitgas, P., Alheit, J., Peck, M., Raab, K., Irigoien, X., Huret, M., van der Kooij, J.,

Pinsky, M.L., Fogarty M., 2012. Lagged social-ecological responses to climate and range shifts in fisheries. Climatic Change 115, 883-891.

Potter, I.C., Beckley, L.E., Whitfield, A.K., Lenanton, R.C.J., 1990. Comparisons between the roles played by estuaries in the life cycles of fishes in temperate Western Australia and Southern Africa. Environ. Biol. Fish. 28, 143-178. 
973 R Core Team (2015). R: A language and environment for statistical computing. R

974 Foundation for Statistical Computing, Vienna, Austria. URL http://www.R975 project.org/.

976 Rayner, N.A., 2003. Global analyses of sea surface temperature, sea ice, and night marine 977 air temperature since the late nineteenth century. J. Geophys. Res. 108, 1-20.

978 Reid, P.C., Edwards, M., Hunt, H.G., Warner, A.J., 1998. Phytoplankton change in the $979 \quad$ North Atlantic. Nature 391, 546.

980 Reid, P., Holliday, N., Smyth, T., 2001. Pulses in the eastern margin current and warmer water off the north west European shelf linked to North Sea ecosystem changes. Mar. Ecol. Prog. Ser. 215, 283-287.

983 Richardson, A.J., 2008. In hot water: zooplankton and climate change. ICES J. Mar. Sci. $65,279-295$.

Rijnsdorp, A.D., Peck, M.A., Engelhard, G.H., Möllmann, C., Pinnegar, J.K., 2009. Resolving the effect of climate change on fish populations. ICES J. Mar. Sci. 66, $1570-1583$.

Rochet, M., Trenkel, V., Bellail, R., Coppin, F., Lepape, O., Mahe, J., Morin, J., Poulard, 989 J., Schlaich, I., Souplet, A., 2005. Combining indicator trends to assess ongoing changes in exploited fish communities: diagnostic of communities off the coasts of France. ICES J. Mar. Sci. 62, 1647-1664.

992 Rossoll, D., Bermúdez, R., Hauss, H., Schulz, K.G., Riebesell, U., Sommer, U., Winder, 993 M., 2012. Ocean Acidification-Induced Food Quality Deterioration Constrains Trophic Transfer. PLoS ONE 7:e34737. 
995 Rowe, C.L., Dunson W.A., 1995. Individual and interactive effects of salinity and initial 996 fish density on a salt marsh assemblage. Mar. Ecol. Prog. Ser. 128, 271-278.

997 Russell, F.S., Southward, A.J., Boalch, G.T., Butler, E.I., 1971. Changes in Biological 998 Conditions in the English Channel off Plymouth during the Last Half Century. Nature 234, 468-470.

1000 Rybarczyk, H., Elkaim, B., Ochs, L., Loquet, N., 2003. Analysis of the trophic network 1001 of a macrotidal ecosystem: the Bay of Somme (Eastern Channel). Estuar. Coast. Shelf S. 58, 405-421.

Saulquin, B., Gohin, F., 2010. Mean seasonal cycle and evolution of the sea surface temperature from satellite and in situ data in the English Channel for the period 1986-2006. Int. J. Remote Sens. 31, 4069-4093.

1006 Seitz, R.D., Wennhage, H., Bergstrom, U., Lipcius, R.N., Ysebaert, T., 2014. Ecological 1007 value of coastal habitats for commercially and ecologically important species. ICES J. Mar. Sci. 71, 648-665.

1009 Şekercioğlu, Ç.H., Primack, R.B., Wormworth, J., 2012. The effects of climate change on 1010 tropical birds. Biol. Conserv. 148, 1-18.

1011 Simpson, S.D., Jennings, S., Johnson, M.P., Blanchard, J.L., Schön, P.J., Sims, D.W., 1012 Genner, M.J., 2011. Continental Shelf-Wide Response of a Fish Assemblage to 1013 Rapid Warming of the Sea. Curr. Biol. 21, 1565-1570.

1014 Singh, S.P., Sharma, J.G., Ahmad, T., Chakrabarti, R., 2013. Effect of Water temperature 1015 on the physiological responses of Asian catfish Claria batrachus (Linnaeus 1758). $1016 \quad$ Asian Fisher. Sci. 26, 26-38. 
1017 Solomon, S., 2007. Intergovernmental Panel on Climate Change, and Intergovernmental 1018 Panel on Climate Change, editors. Climate change 2007: the physical science basis: contribution of Working Group I to the Fourth Assessment Report of the Intergovernmental Panel on Climate Change. Cambridge University Press, Cambridge, New York.

Somero, G.N., 2010. The physiology of climate change: how potentials for acclimatization and genetic adaptation will determine "winners" and "losers." J. Exp. Biol. 213, 912-920.

Stenseth, N.C., Mysterud, A., Ottersen, G., Hurrell, J.W., Chan, K.S., Lima, M., 2002. Ecological effects of climate fluctuations. Science 297, 1292-1296.

Stramma, L., Schmidtko, S., Levin, L.A., Johnson, G.C., 2010. Ocean oxygen minima expansions and their biological impacts. Deep Sea Research Part I: Oceanogr. Res. Pap. 57, 587-595.

Sunday, J.M., Bates, A.E., Dulvy, N.K., 2011. Global analysis of thermal tolerance and latitude in ectotherms. P. Roy. Soc. B. Bio. 278, 1823-1830.

Ter Hofstede, R., Hiddink, J., Rijnsdorp, A., 2010. Regional warming changes fish species richness in the eastern North Atlantic Ocean. Mar. Ecol. Prog. Ser. 414, 19.

Thiel, R., Sepulveda, A., Kafemann, R., Nellen, W., 1995. Environmental factors as forces structuring the fish community of the Elbe Estuary. J. Fish Biol. 46, 47-69. herring (Clupea harengus, Clupeidae) throughout the 20th century and the influence of climatic fluctuations. Fish Fish. 1, 231-256. 
1040 Trigo, R.M., Pozo-Vázquez, D., Osborn, T.J., Castro-Díez, Y., Gámiz-Fortis, S., Esteban-

1041

1042

1043

1044

1045

1046

1047

1048

1049

1050

1051

1052

1053

1054

1055

1056

1057

1058

1059

1060

1061

1062 Parra, M.J., 2004. North Atlantic oscillation influence on precipitation, river flow and water resources in the Iberian Peninsula. Int. J. Climatol. 24, 925-944.

Tsikliras, A.C., Stergiou, K.I., 2014. Mean temperature of the catch increases quickly in the Mediterranean Sea. Mar. Ecol. Prog. Ser.. 515, 281-284.

Tsikliras, A.C., Peristeraki, P., Tserpes, G., Stergiou, K.I., 2015. Mean temperature of the catch (MTC) in the Greek Seas based on landings and survey data. Front. Mar. Sci. 2, 2-23.

Verges, A., Steinberg, P.D., Hay, M.E., Poore, A.G.B., Campbell, A.H., Ballesteros, E., Heck, K.L., Booth, D.J., Coleman, M.A., Feary, D.A., Figueira, W., Langlois, T., Marzinelli, E.M., Mizerek, T., Mumby, P.J., Nakamura, Y., Roughan, M., van Sebille, E., Gupta, A.S., Smale, D.A., Tomas, F., Wernberg, T., Wilson, S.K., 2014. The tropicalization of temperate marine ecosystems: climate-mediated changes in herbivory and community phase shifts. P. Roy. Soc. B. Bio. 281:20140846.

Walker K., Graf, H.F., 2005. The North Atlantic variability structure, storm tracks, and precipitation depending on the polar vortex strength. Atmos. Chem. Phys. 5, 239248.

Wang, C., Dong, S., 2010. Is the basin-wide warming in the North Atlantic Ocean related to atmospheric carbon dioxide and global warming? Geophys. Res. Lett. 37, 1-5.

Wetz, M.S., Hutchinson, E.A., Lunetta, R.S., Paerl, H.W., Christopher Taylor, J., 2011. Severe droughts reduce estuarine primary productivity with cascading effects on higher trophic levels. Limnol. Oceanogr. 56, 627-638. 
1063 Whitfield, A., Elliott, M., 2002. Fishes as indicators of environmental and ecological

1064 changes within estuaries: a review of progress and some suggestions for the

1065 future. J. Fish Biol. 61, 229-250.

1066 Zepp, R.G., Callaghan, T.V., Erickson, D.J., 2003. Interactive effects of ozone depletion

1067 and climate change on biogeochemical cyclesThis article is published as part of

1068 the United Nations Environmental Programme: Environmental effects of ozone

1069 depletion and its interactions with climate change: 2002 assessment. Photochem.

$1070 \quad$ Photobiol. Sci. 2, 51-61.

1071 
1072 Figure captions:

1073 Fig. 1. The Bay of Somme with locations of sampling sites and meteorological stations of

1074 Dieppe and Noyelles-sur-Mer.

1075 Fig. 2. Temporal dynamics of the fish community structure in the Bay of Somme from

10761980 to 2012. Shaded grey represents the "breaking year" (1998). PC1 and PC2

1077 explained 20 and $10 \%$ of total variation, respectively.

1078 Fig. 3. Radar plot comparing fish abundances before and after 1998 in the Bay of Somme

1079 (nb.ind. $\mathrm{km}^{2} ; \log _{10}$ transformed). Results of permutation tests for changes in taxa

1080 abundance before and after 1998 accounting for multiple testing: ***: $p<0.001$; **:

$1081 \quad 0.001<p<0.01 ; *: 0.01<p<0.05$

1082 Fig. 4. A. Cross-correlation plot between the index of global conditions $\left(\mathrm{PC} 1_{\text {global }}\right)$ and

1083 the index of fish community structure $\left(\mathrm{PC1}_{\text {taxo }}\right)$. B. Cross-correlation plot between the

1084 index of local conditions $\left(\mathrm{PC}_{\text {local }}\right)$ and the index of fish community structure $\left(\mathrm{PC} 1_{\text {taxo }}\right)$.

1085 Fig. 5. Temporal dynamics of the Mean Temperature of the Catch index (MTC).

1086 Fig. 6. A. Structure of the fish community before and after 1998 according to thermal

1087 preferences. Results of permutation tests for change in each "thermal group" before and

1088 after 1998 accounting for multiple testing: $* * *: p<0.001 ; * *: 0.001<p<0.01 ; *: 0.01<p$

$1089<0.05$. B. Thermal preferences and trends of abundance variation (increase/decrease) of

1090 each species between the two tested periods. Underlined species changed significantly in

1091 abundance between the two periods. C. Thermal preferences of species that decreased in

1092 abundance over time.

1093 Fig. 7. A. Temporal dynamics of the taxonomic structure of the fish community $\left(\mathrm{PC} 1_{\text {taxo }}\right)$

1094 and AMO. B. Thermal structure $\left(\mathrm{PC} 1_{\text {therm }}\right)$ and AMO. C. Taxonomic structure $\left(\mathrm{PC}_{\text {taxo }}\right)$ 
1095 and local SST. D. Thermal structure $\left(\mathrm{PC}_{\text {therm }}\right)$ and local SST. PC1 $1_{\text {taxo }}$ explains $19 \%$ of

1096 total variation of the taxonomic structure of the community and $\mathrm{PC} 1_{\text {therm }}$ explains $27 \%$ of

1097 total variation of the thermal structure of the community.

1098 Fig. 8. Potential mechanisms of effects related to temperature change on the structure of 1099 the fish community. Each arrow indicates a potential effect.

1100

1101 
1102 Table 1. Pearson correlation results ( $\mathrm{p}$-values and $\mathrm{R}^{2}$ ) between $\mathrm{PC} 1_{\text {taxo }}$ and $\mathrm{AMO}, \mathrm{PC} 1_{\text {taxo }}$

1103 and local SST, PC1 $1_{\text {therm }}$ and AMO, PC $1_{\text {therm }}$ and local SST with four time-lags $(0,1,2$ and

11043 years). Shaded cells correspond to significant correlations.

1105

\begin{tabular}{|c|c|c|c|c|c|}
\hline & \multicolumn{2}{|c|}{$\sum_{<}^{O}$} & \multicolumn{2}{|c|}{$\begin{array}{l}\frac{5}{\widetilde{n}} \\
\frac{\widetilde{J}}{\circ}\end{array}$} \\
\hline & & 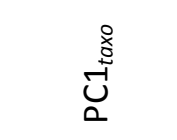 & 㺼 & 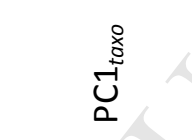 & ปัँّ \\
\hline \multirow{4}{*}{$\begin{array}{c}\text { time } \\
\text { lag } \\
\text { (years) }\end{array}$} & 0 & $\begin{array}{l}p=0.113 ; \\
R^{2}=0.13\end{array}$ & $\begin{array}{l}p=0.001 ; \\
R^{2}=0.43\end{array}$ & $\begin{array}{l}p=0.219 \\
R^{2}=0.078\end{array}$ & $\begin{array}{l}p=0.439 ; \\
R^{2}=0.03\end{array}$ \\
\hline & 1 & $\begin{array}{l}p=0.048 ; \\
R^{2}=0.2\end{array}$ & $\begin{array}{l}p=0.022 ; \\
R^{2}=0.26\end{array}$ & $\begin{array}{l}p=0.05 \\
R^{2}=0.19\end{array}$ & $\begin{array}{l}p=0.169 \\
R^{2}=0.11\end{array}$ \\
\hline & 2 & $\begin{array}{l}p=0.008 ; \\
R^{2}=0.35\end{array}$ & $\begin{array}{l}p=0.004 ; \\
R^{2}=0.38\end{array}$ & $\begin{array}{l}p=0.193 ; \\
R^{2}=0.09\end{array}$ & $\begin{array}{l}p=0.428 ; \\
R^{2}=0.04\end{array}$ \\
\hline & 3 & $\begin{array}{l}p=0.396 \\
R^{2}=0.04\end{array}$ & $\begin{array}{l}p=6.7 e-04 ; \\
R^{2}=0.52\end{array}$ & $\begin{array}{l}p=0.065 \\
\mathrm{R}^{2}=0.19\end{array}$ & $\begin{array}{l}p=0.055 ; \\
R^{2}=0.21\end{array}$ \\
\hline
\end{tabular}

1106 
1107 Table 2. Pearson correlation results (p-values and r) between MTC and temperature-

1108 related indices with four time-lags $(0,1,2$ and 3 years $)$. Shaded cells correspond to 1109 significant correlations.

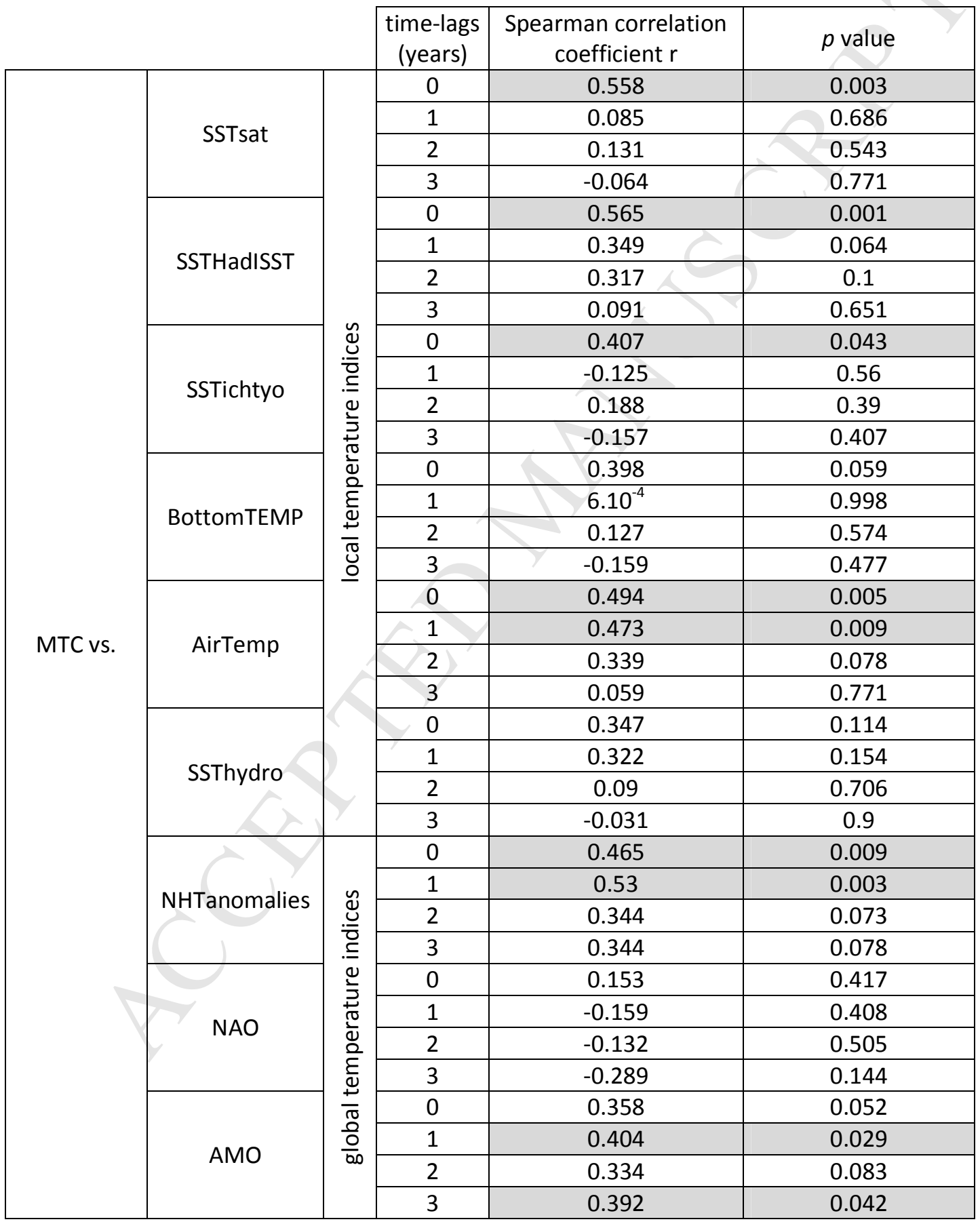

1110 
1111

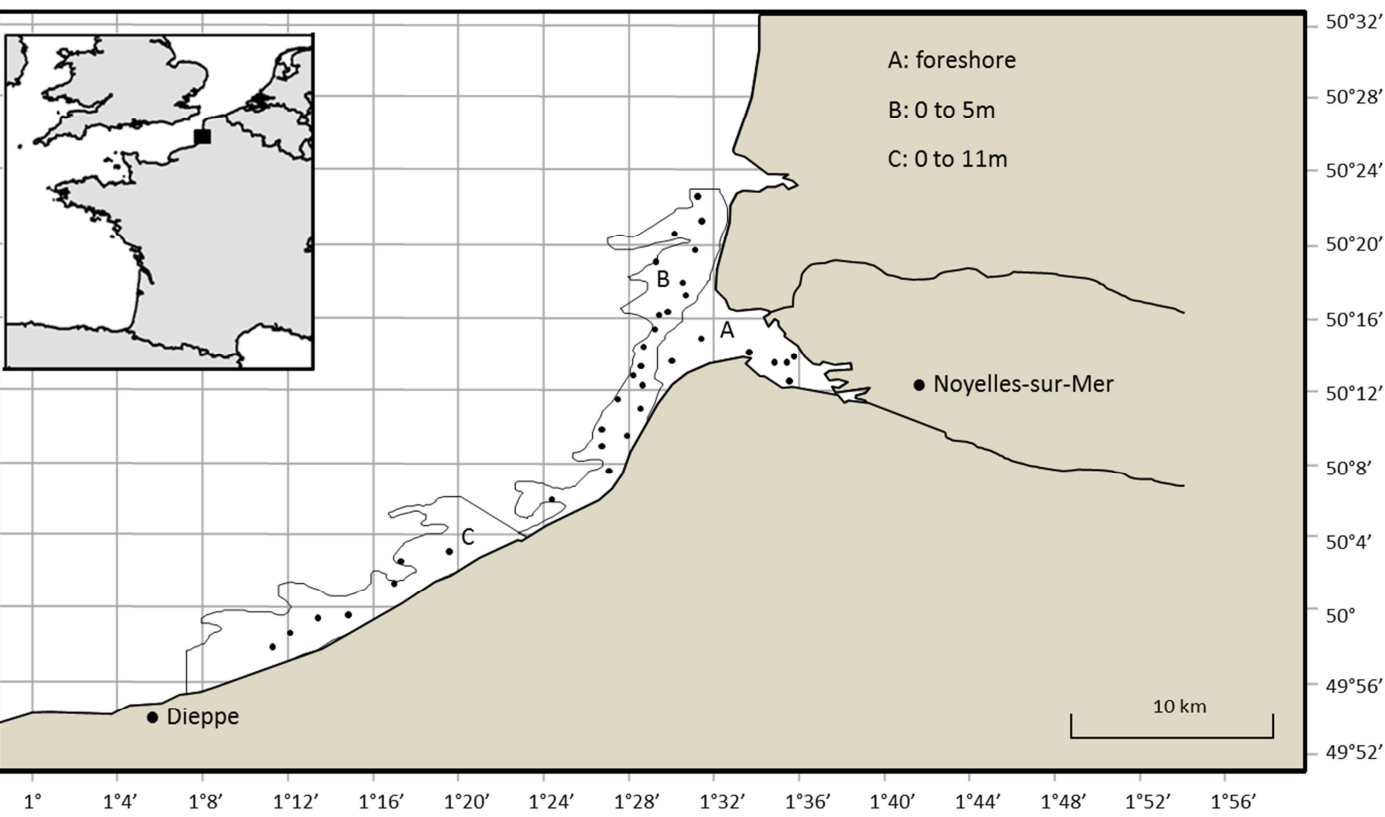

1112

Figure 1. 


\section{4}

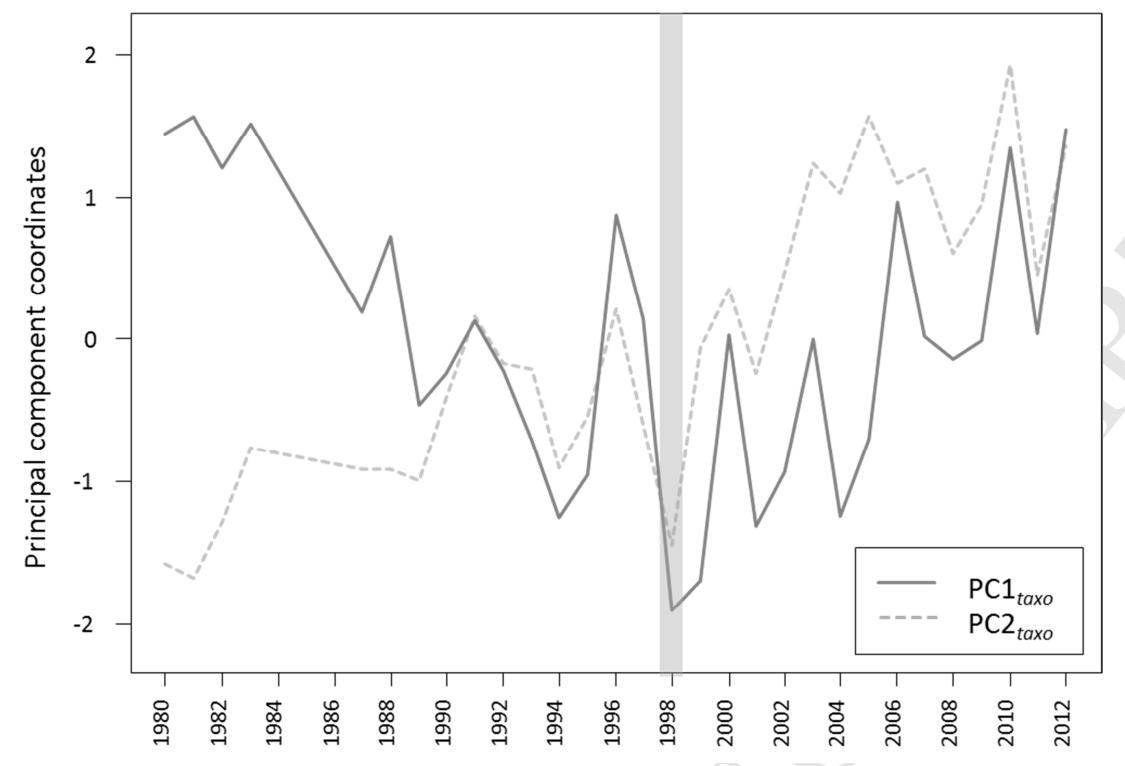

1115 Figure 2. 


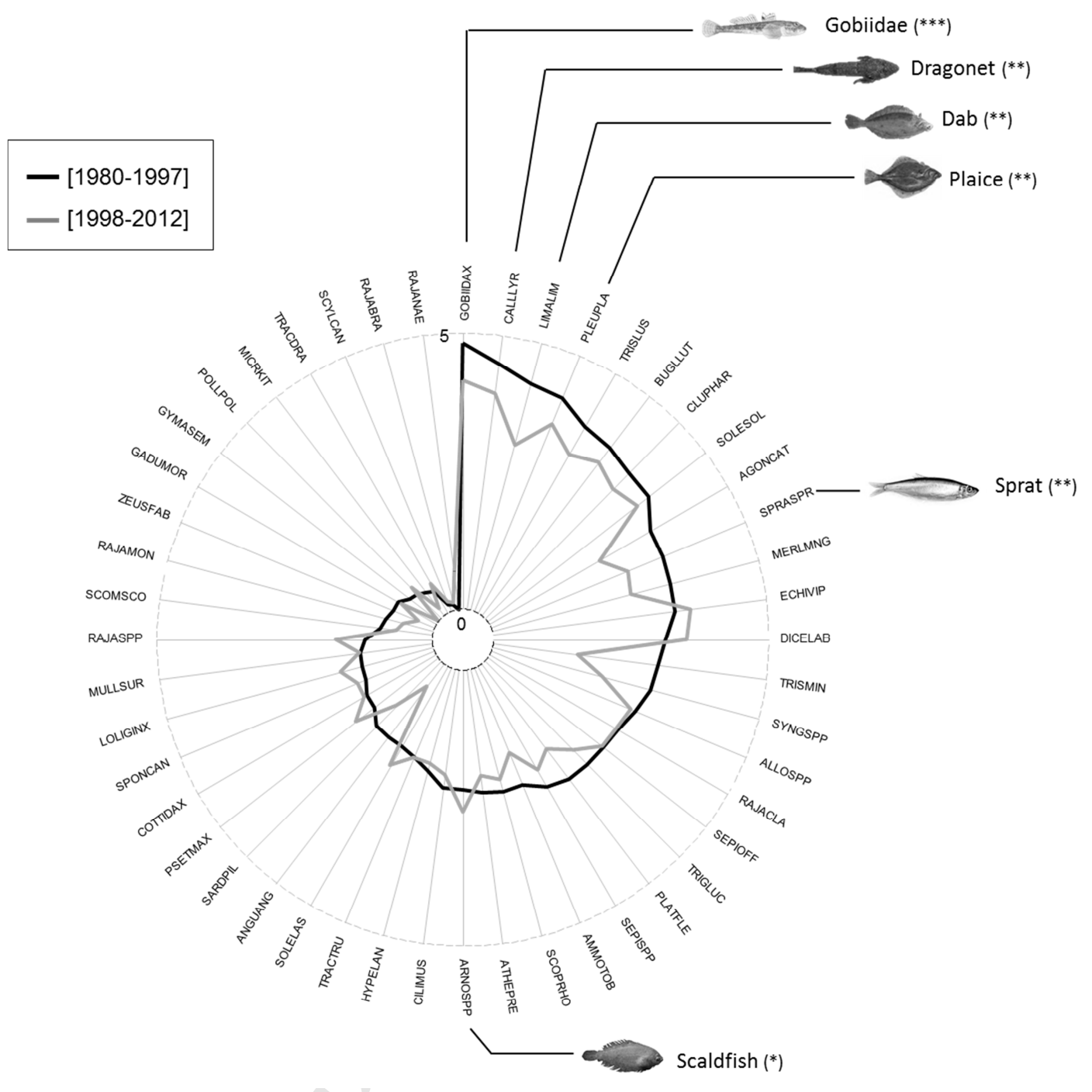

1116

Figure 3. 

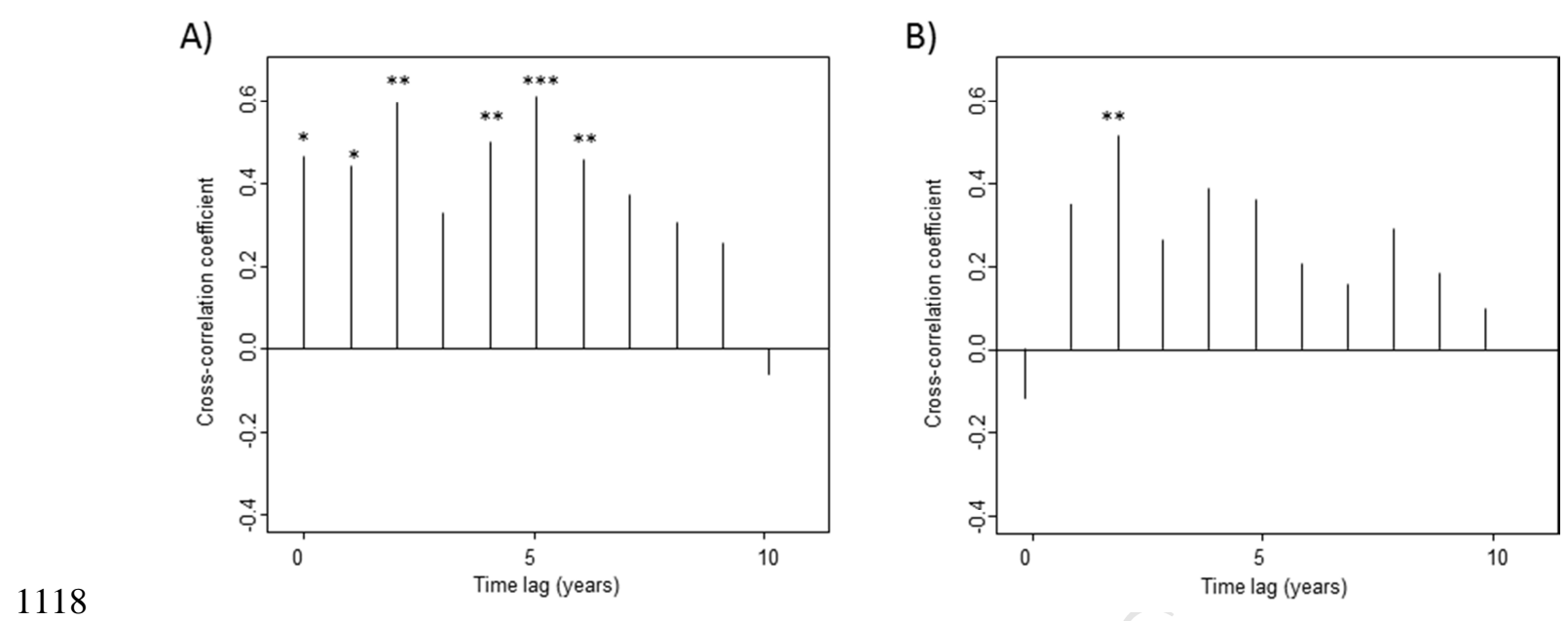

1119 Figure 4.

1120

1121 


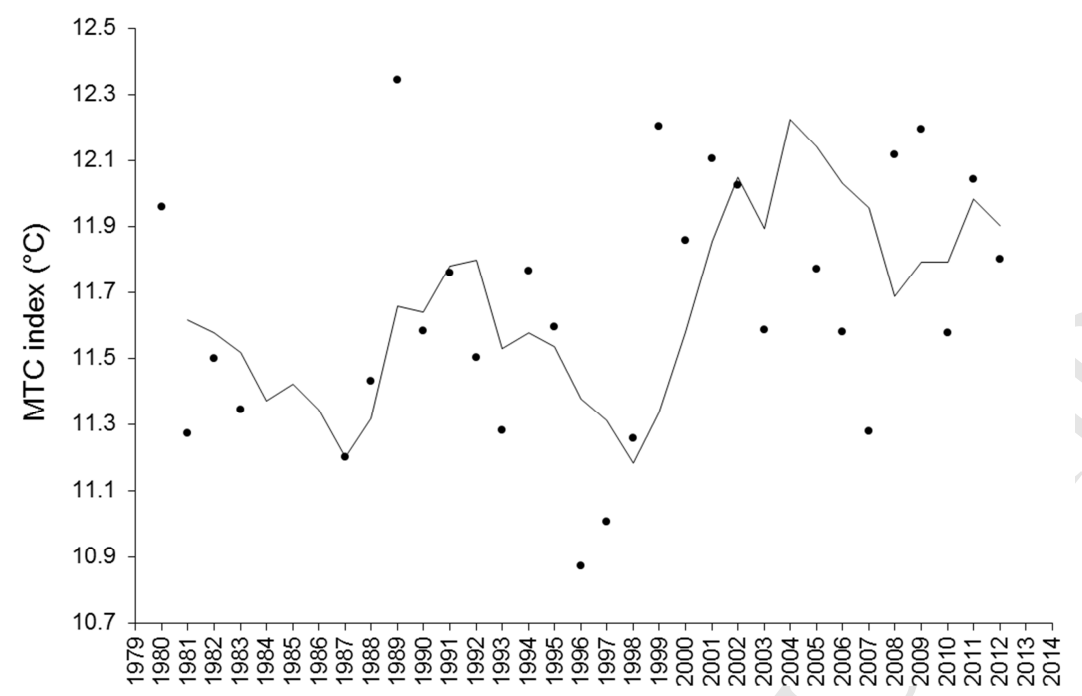

1123 Figure 5. 
A)

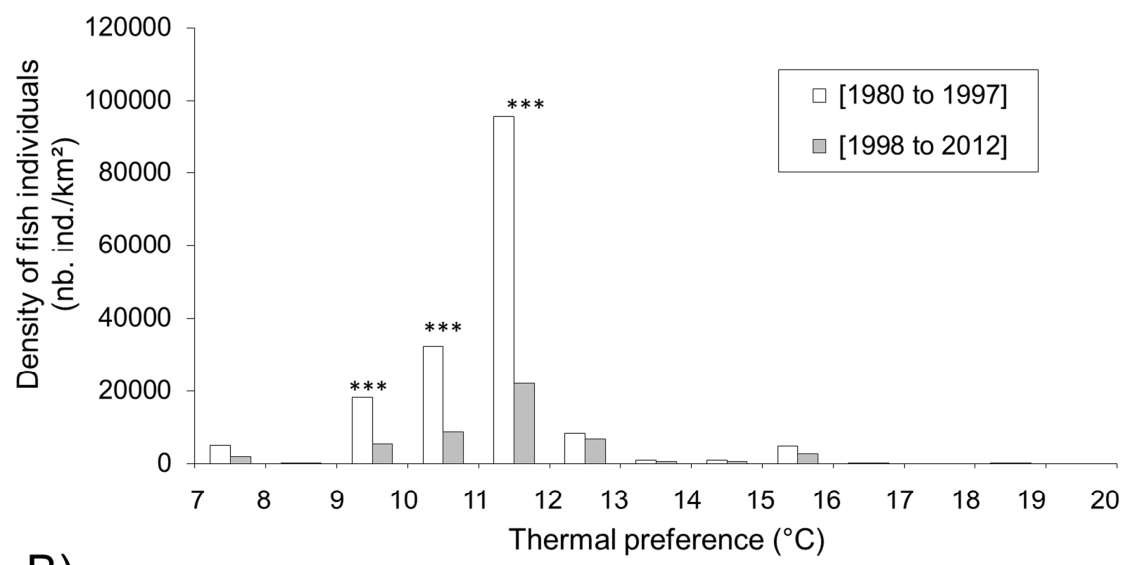

B)

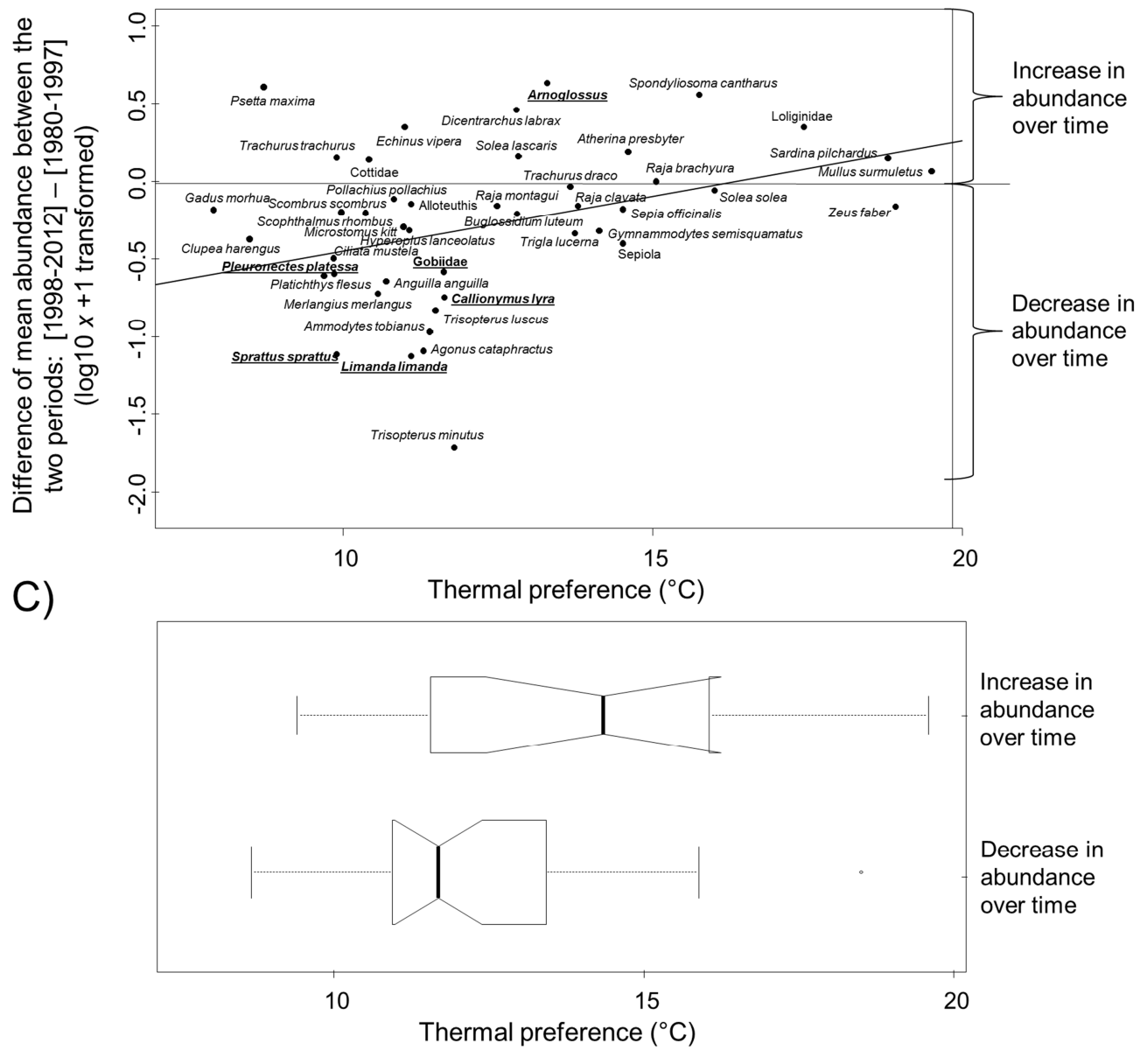

1125 Figure 6. 


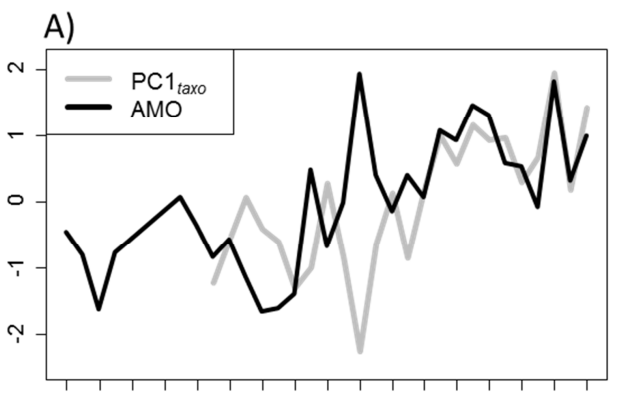

198019841988199219962000200420082012 C)

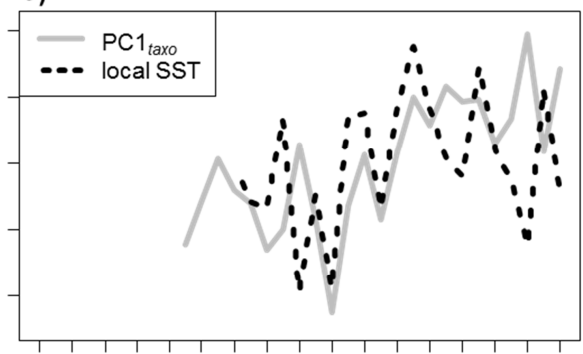

1126
B)

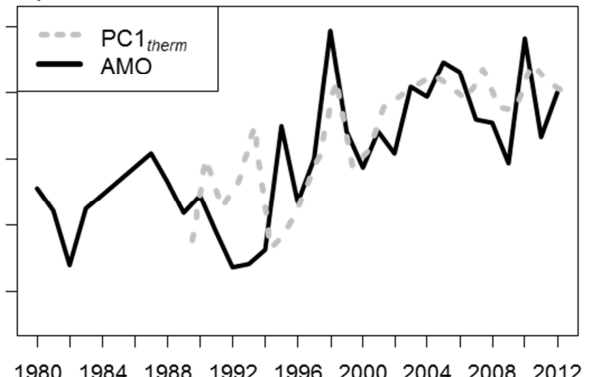

D)

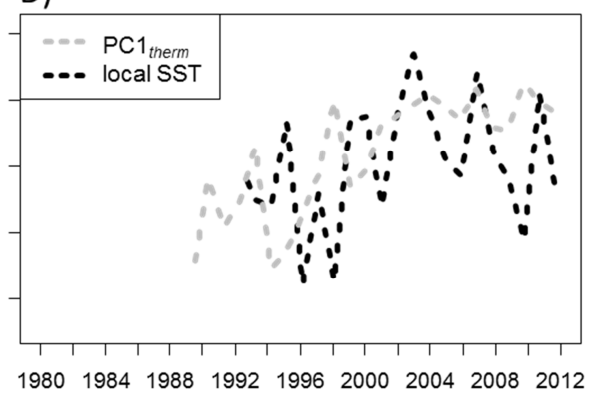

1127 Figure 7. 


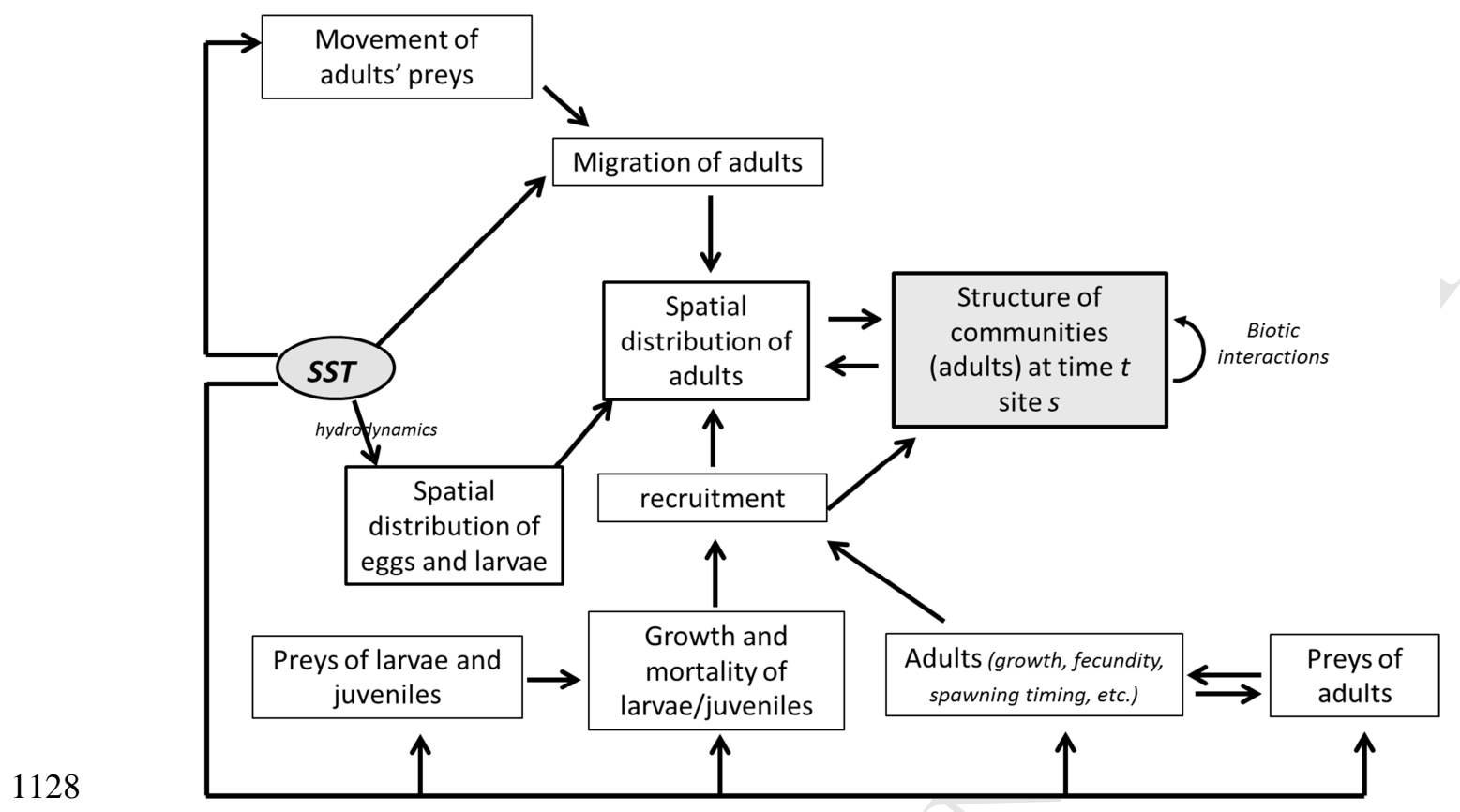

1129 Figure 8.

1130

1131 